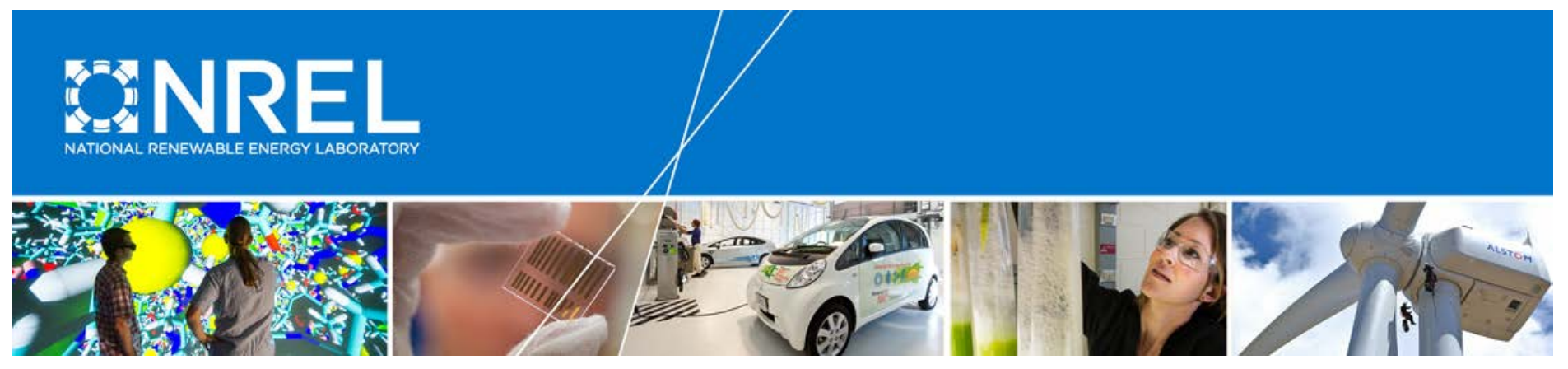

\title{
Fuel Cell Buses in U.S. Transit Fleets: Current Status 2016
}

Leslie Eudy, Matthew Post, and Matthew Jeffers National Renewable Energy Laboratory

NREL is a national laboratory of the U.S. Department of Energy Office of Energy Efficiency \& Renewable Energy Operated by the Alliance for Sustainable Energy, LLC

This report is available at no cost from the National Renewable Energy Laboratory (NREL) at www.nrel.gov/publications.

Technical Report

NREL/TP-5400-67097

November 2016

Contract No. DE-AC36-08G028308 


\title{
Fuel Cell Buses in U.S. Transit Fleets: Current Status 2016
}

\author{
Leslie Eudy, Matthew Post, and Matthew Jeffers \\ National Renewable Energy Laboratory
}

Prepared under Task No. HT12.8210

NREL is a national laboratory of the U.S. Department of Energy Office of Energy Efficiency \& Renewable Energy Operated by the Alliance for Sustainable Energy, LLC

This report is available at no cost from the National Renewable Energy Laboratory (NREL) at www.nrel.gov/publications.

National Renewable Energy Laboratory 15013 Denver West Parkway Golden, CO 80401

303-275-3000 • www.nrel.gov
Technical Report NREL/TP-5400-67097

November 2016

Contract No. DE-AC36-08GO28308 


\section{NOTICE}

This report was prepared as an account of work sponsored by an agency of the United States government. Neither the United States government nor any agency thereof, nor any of their employees, makes any warranty, express or implied, or assumes any legal liability or responsibility for the accuracy, completeness, or usefulness of any information, apparatus, product, or process disclosed, or represents that its use would not infringe privately owned rights. Reference herein to any specific commercial product, process, or service by trade name, trademark, manufacturer, or otherwise does not necessarily constitute or imply its endorsement, recommendation, or favoring by the United States government or any agency thereof. The views and opinions of authors expressed herein do not necessarily state or reflect those of the United States government or any agency thereof.

This report is available at no cost from the National Renewable Energy Laboratory (NREL) at www.nrel.gov/publications.

Available electronically at SciTech Connect http:/www.osti.gov/scitech

Available for a processing fee to U.S. Department of Energy and its contractors, in paper, from:

U.S. Department of Energy

Office of Scientific and Technical Information

P.O. Box 62

Oak Ridge, TN 37831-0062

OSTI http://www.osti.gov

Phone: 865.576.8401

Fax: 865.576.5728

Email: reports@osti.gov

Available for sale to the public, in paper, from:

U.S. Department of Commerce

National Technical Information Service

5301 Shawnee Road

Alexandria, VA 22312

NTIS http://www.ntis.gov

Phone: 800.553 .6847 or 703.605 .6000

Fax: 703.605.6900

Email: orders@ntis.gov 


\section{Acknowledgments}

This document includes results and experiences from several U.S. fuel cell electric bus evaluation projects. The active participation of our project partners is greatly appreciated. Contributors to this report included staff members of federal and state government agencies, manufacturing firms, and transit authorities. The authors especially thank the following individuals:

Salvador Llamas, Roland Fecteau, Chris Durant, and Jose Vega, Alameda-Contra Costa Transit District

Tommy Edwards and Mike Hayes, SunLine Transit Agency

Analy Castillo, Brendan Shaffer, and Tim Rudek, University of California at Irvine

Steve Miller, Golden Gate Transit

Jason Marcinkoski, U.S. Department of Energy

Christina Gikakis and Sean Ricketson, U.S. Department of Transportation, Federal Transit Administration

Byron Somerville, Steve Potvin, George Morales, Ballard Power Systems

Robert Devine and Yesh Premkumar, BAE Systems

Abas Goodarzi, US Hybrid

Nico Bouwkamp, California Fuel Cell Partnership

Yachun Chow, Jennifer Lee, California Air Resources Board

Erik Bigelow, Jaimie Levin, and Roxana Bekemohammadi, Center for Transportation and the Environment

Keith Wipke and Jen Kurtz, National Renewable Energy Laboratory 


\section{Acronyms and Abbreviations}

AC Transit

AFCB

BJCTA

CARB

CEC

$\mathrm{CNG}$

DGE

DOE

FCEB

FCPP

$\mathrm{ft}$

FTA

GGE

$\mathrm{kg}$

MBRC

mph

NFCBP

NREL

OEM

NTD

TIGGER

TMRL

TRL

UCI

ZEB

ZEBA
Alameda-Contra Costa Transit District

American Fuel Cell Bus

Birmingham-Jefferson County Transit Authority

California Air Resources Board

California Energy Commission

compressed natural gas

diesel gallon equivalent

U.S. Department of Energy

fuel cell electric bus

fuel cell power plant

foot

Federal Transit Administration

gasoline gallon equivalent

kilograms

miles between roadcalls

miles per hour

National Fuel Cell Bus Program

National Renewable Energy Laboratory

original equipment manufacturer

National Transit Database

Transit Investments for Greenhouse Gas and Energy

Reduction

technology maintenance readiness level

technology readiness level

University of California at Irvine

zero emission bus

Zero Emission Bay Area 


\section{Definition of Terms}

Availability: The number of days the buses are actually available compared to the days that the buses are planned for operation expressed as percent availability.

Balance of plant: The components of the fuel cell system - such as air compressor, fans, and pumps - that support the operation of the fuel cell stack.

Clean point: The starting point for the data analysis period. For each evaluation, NREL works with the project partners to determine a starting point—or clean point—-for the data analysis period. The clean point is chosen to avoid some of the early and expected operations problems with a new vehicle going into service, such as early maintenance campaigns. In some cases, reaching the clean point may require 3 to 6 months of operation before the evaluation can start.

Fast-fill: Per the Society of Automotive Engineers J2601/2, a flow rate of 61 to 120 grams per second is considered a fast-fill. Transit agencies have a goal of completing a full fill of a hydrogen-fueled bus in 10 minutes or less.

Miles between roadcalls (MBRC): A measure of reliability calculated by dividing the number of miles traveled by the number of roadcalls. (Also known as mean distance between failures.) MBRC results in the report are categorized as follows:

- Bus MBRC: Includes all chargeable roadcalls. Includes propulsion-related issues as well as problems with bus-related systems such as brakes, suspension, steering, windows, doors, and tires.

- Propulsion-related MBRC: Includes roadcalls that are attributed to the propulsion system. Propulsion-related roadcalls can be caused by issues with the power system (fuel cell), batteries, and hybrid systems.

- Fuel-cell-system-related MBRC: Includes roadcalls attributed to the fuel cell power plant and balance of plant only.

Revenue service: The time when a vehicle is available to the general public with an expectation of carrying fare-paying passengers. Vehicles operated in a fare-free service are also considered revenue service.

Roadcall: A failure of an in-service bus that causes the bus to be replaced on route or causes a significant delay in schedule. The analysis includes chargeable roadcalls that affect the operation of the bus or may cause a safety hazard. Non-chargeable roadcalls can be passenger incidents that require the bus to be cleaned before going back into service or problems with an accessory such as a farebox or radio. 


\section{Executive Summary}

This report, published annually, summarizes the progress of fuel cell electric bus (FCEB) development in the United States and discusses the achievements and challenges of introducing fuel cell propulsion in transit. The report provides a summary of results from evaluations performed by the National Renewable Energy Laboratory (NREL). Funding for this effort is provided by the U.S. Department of Energy's (DOE's) Fuel Cell Technologies Office within the Office of Energy Efficiency and Renewable Energy and by the U.S. Department of Transportation's Federal Transit Administration (FTA).

NREL publishes individual reports on each demonstration that focus on the results and experiences for that specific project. The annual status report combines results from all of those FCEB demonstrations, tracks the progress of the FCEB industry toward meeting technical targets (as shown in Table ES-1), documents the lessons learned, and discusses the path forward for commercial viability of fuel cell technology for transit buses. Its intent is to inform FTA and DOE decision makers who direct research and funding, state and local government agencies that fund new propulsion technology transit buses, and interested transit agencies and industry manufacturers.

The 2016 summary results primarily focus on the most recent year for each demonstration, from August 2015 through July 2016. The results for these buses account for more than 550,000 miles traveled and 59,500 hours of fuel cell power system operation. The primary results presented in the report are from three demonstrations of two different fuel-cell-dominant bus designs:

- Zero Emission Bay Area Demonstration Group led by Alameda-Contra Costa Transit District (AC Transit) in California

- American Fuel Cell Bus Project at SunLine Transit Agency in California

- American Fuel Cell Bus Project at the University of California at Irvine (UCI).

NREL considers these FCEB designs to be around technology readiness level (TRL) 7, that is, full-scale validation in a relevant environment. At this point in development, capital and operating costs for FCEBs are still much higher than those of conventional diesel technology. This is to be expected considering diesel is a very mature technology (TRL 9) and FCEBs are still in the development stage.

NREL collected and analyzed conventional baseline bus data from each site for comparison with the FCEB data. The baseline buses are selected to be as close a match to the FCEBs as possible and they are operated in similar service scenarios. At AC Transit, the baseline buses are diesel buses. The baseline buses at SunLine are compressed natural gas buses because the agency does not operate diesel buses. UCI has a small fleet of diesel buses; however, those buses are much older and are not similar in size and weight. NREL is not collecting baseline data for that demonstration.

DOE and FTA have established performance and cost targets for FCEBs. These targets, established with industry input, include interim targets for 2016 and ultimate targets for commercialization. FCEB technology continues to show progress toward meeting technical 
targets for increasing reliability and durability while also reducing costs. Table ES-1 summarizes the performance of the FCEBs in the report compared to these targets.

Table ES-1. Summary of FCEB Performance Compared to DOE/FTA Targets ${ }^{1}$

\begin{tabular}{|c|c|c|c|c|}
\hline & Units & $\begin{array}{l}\text { Current Status }{ }^{a} \\
\text { (Range) }\end{array}$ & $\begin{array}{l}2016 \\
\text { Target }^{1}\end{array}$ & $\begin{array}{l}\text { Ultimate } \\
\text { Target }\end{array}$ \\
\hline Bus lifetime & years/miles & $\begin{array}{c}0.8-6 / \\
22,700-155,000^{b}\end{array}$ & $12 / 500,000$ & $12 / 500,000$ \\
\hline Power plant lifetime $^{C}$ & hours & $2,300-23,000^{b, d, e}$ & 18,000 & 25,000 \\
\hline Bus availability & $\%$ & $32-93$ & 85 & 90 \\
\hline Fuel fills ${ }^{f}$ & per day & 1 & $1(<10 \mathrm{~min})$ & $1(<10 \mathrm{~min})$ \\
\hline Bus cost ${ }^{g}$ & $\$$ & $1.8 \mathrm{M}-2.5 \mathrm{M}^{\mathrm{h}}$ & $1,000,000$ & 600,000 \\
\hline $\begin{array}{l}\text { Roadcall frequency } \\
\text { (bus/fuel cell system) }\end{array}$ & $\begin{array}{l}\text { miles between } \\
\text { roadcalls }\end{array}$ & $\begin{array}{c}2,500-7,400 / \\
7,900-143,800\end{array}$ & $\begin{array}{l}3,500 / \\
15,000\end{array}$ & $\begin{array}{l}4,000 / \\
20,000\end{array}$ \\
\hline Operation time & $\begin{array}{c}\text { hours per } \\
\text { day/days per } \\
\text { week }\end{array}$ & $\begin{array}{l}7-21 / \\
5-7\end{array}$ & $20 / 7$ & $20 / 7$ \\
\hline $\begin{array}{l}\text { Scheduled and } \\
\text { unscheduled } \\
\text { maintenance cost }\end{array}$ & \$/mile & $0.46-2.06$ & 0.75 & 0.40 \\
\hline Range $^{\mathrm{j}}$ & miles & $165-298$ & 300 & 300 \\
\hline Fuel economy & $\begin{array}{c}\text { miles per diesel } \\
\text { gallon equivalent }\end{array}$ & $4.91-7.09$ & 8 & 8 \\
\hline
\end{tabular}

${ }^{a}$ The summary of results in this report represents a snapshot from the included demonstrations: data from August 2015 to July 2016.

${ }^{\mathrm{b}}$ Accumulated totals for existing fleet through July 2016; these buses have not reached end of life.

${ }^{\mathrm{c}}$ For the DOE/FTA targets, the power plant is defined as the fuel cell system and the battery system. The fuel cell system includes supporting subsystems such as the air, fuel, coolant, and control subsystems. Power electronics, electric drive, and hydrogen storage tanks are excluded.

${ }^{\mathrm{d}}$ The status for power plant hours is for the fuel cell system only; battery lifetime hours were not available.

${ }^{\mathrm{e}}$ The highest-hour power plant was transferred from an older-generation bus that had accumulated more than 6,000 hours prior to transfer.

${ }^{\mathrm{f}}$ Multiple sequential fuel fills should be possible without an increase in fill time.

${ }^{\mathrm{g}}$ Cost targets are projected to a production volume of 400 systems per year. This production volume is assumed for analysis purposes only and does not represent an anticipated level of sales.

${ }^{\mathrm{h}}$ Reported cost of most recent orders for FCEBs was $\$ 1.8$ million.

${ }^{\mathrm{i}}$ Excludes mid-life overhaul of power plant.

${ }^{\mathrm{j}}$ Based on fuel economy and $95 \%$ tank capacity.

DOE/FTA set an ultimate performance target of 4 to 6 years (or 25,000 hours) durability for the fuel cell propulsion system, with an interim target of 18,000 hours by 2016. Manufacturers continue to make significant progress toward meeting the target. In last year's report, NREL documented a single fuel cell power plant surpassing the 2016 target. At the end of the analysis period for this report (July 2016), that fuel cell power plant had reached 23,000 hours, nearing the ultimate target of 25,000 hours. A second fuel cell power plant has now surpassed the 2016 target, achieving 18,293 hours. Of the 18 fuel cell power plants included in the data set, 67\% (12) have surpassed 13,000 hours of operation. The average hours accumulated is 12,302 .

\footnotetext{
${ }^{1}$ Fuel Cell Technologies Program Record \# 12012, September 12, 2012, www.hydrogen.energy.gov/pdfs/12012 fuel_cell_bus targets.pdf.
} 
Availability continues to vary from site to site with per-bus data from the last year ranging from a low of $32 \%$ to a high of $93 \%$, with the overall average at $77 \%$. This is slightly higher than what was reported last year (74\% average availability). Many of the issues are attributed to bus-related problems such as brakes, suspension, and air conditioning. Hybrid system problems included issues with components such as traction motor, cooling system, and inverters. Downtime has been extended in some cases because parts have not been readily available. Transit staff continues to learn about the systems and become more proficient in troubleshooting and repairing issues. Downtime is expected to decrease over time.

The targets for roadcall frequency include miles between roadcalls (MBRC) for the entire bus and MBRC for the fuel cell system only. The fuel cell system MBRC includes any roadcalls due to issues with the fuel cell stack or associated balance of plant. The overall MBRC was 4,198 for the bus and 21,036 for the fuel cell system. Bus MBRC continues to show a general upward trend since surpassing the ultimate target around May 2015. Fuel cell system MBRC also shows an upward trend over time, however several roadcalls during the last year have caused the MBRC to drop. The overall fuel cell system MBRC is still greater than the ultimate target.

The FCEBs continue to show higher fuel economy compared to the baseline buses in similar service. FTA's performance target for FCEB fuel economy is 8 miles per diesel gallon equivalent (DGE), which is approximately 2 times higher than that of typical conventional diesel buses. Actual data from the FCEBs included in this report showed fuel economy 1.4 times higher than that of diesel baseline buses (AC Transit) and 1.9 times higher than that of compressed natural gas baseline buses (SunLine). The average fuel economy for both types of FCEBs over the last year was 6.1 miles per DGE. The fuel economy for the FCEBs has shown a decrease over time. This could be due to a variety of factors including changes in duty cycle, temperature, operator driving styles, fuel cell power plant degradation, and hydrogen station metering differences.

FCEB performance continues to improve; however, there are still challenges to overcome to make the technology commercially viable. Challenges include the following:

Parts supply_-Both AC Transit and SunLine continue to experience some issues with availability of bus components that have a long lead time for delivery. This has improved over time as the project partners have learned what should be kept on hand. In some cases, bus components for the FCEB model are different from that of the diesel model so the bus parts inventory cannot be shared. The industry needs to further develop a robust supply chain or more shared components for these advanced components for FCEBs (as well as other electric drive buses).

Bus range/low fuel-AC Transit has reported that real-world bus range is lower than expected. Several factors contribute to the issue including operator familiarity and comfort level with the system, the fueling process, and differences in fueling rate between the two hydrogen stations. The flow rate of the station has an impact on the amount of hydrogen delivered to the tanks. The agency is addressing this challenge through continued training for operator and maintenance staff. It is difficult to measure real-world range because transit agencies typically fill the buses each day, regardless of the amount of fuel left in the tank. Over the last year, the average fill amount is $22.4 \mathrm{~kg}$ for the three evaluated fleets. This amount is less than $60 \%$ of the tank

viii 
capacity. The buses are averaging 121 miles per day. This is more a function of how the buses are scheduled as opposed to the actual capability of the bus.

Retention of trained maintenance staff-All transit agencies are experiencing issues with turnover of the most experienced staff through retirements or job changes. Fewer people are entering the field of technical repair, making new candidates scarce. This is particularly challenging for agencies with advanced technology buses, because technical schools are just now beginning to develop courses to handle maintenance and repair of these new technologies. Once these courses are available, there will be a lag time before graduates are ready to enter the market.

Maintenance costs for FCEBs-Maintenance costs for advanced-technology buses typically start low because the buses are under warranty and the manufacturer is covering the cost and taking an active, on-site role in troubleshooting and repair. Costs begin to increase as transit staff takes on more of the maintenance responsibilities and begins the learning curve to understand how to fully maintain the buses. As the staff becomes more proficient, the costs eventually stabilize. NREL does not include warranty costs in its analysis because that initial warranty is covered in the purchase price for the bus. The uncertainty for FCEBs at this point in development is how the parts costs will affect the overall maintenance costs over time once all the buses are out of the initial warranty period. For AC Transit, the buses are out of the original warranty period and parts costs have increased dramatically. The costs for advanced-technology parts are also much higher than those for conventional technology parts. AC Transit has purchased extended support agreements with the manufacturers that also add to the cost and are included in the NREL analysis. The buses at SunLine and UCI are still under warranty; therefore costs to the agencies are primarily for labor. To help with future planning, transit agencies need to understand future costs as the technology moves into early commercial deployment. Standardization and manufacturing processes could help lower costs for advanced-technology parts and components.

The transition of knowledge from the manufacturers to the transit staff is essential to commercializing the technology. NREL has developed a guide for advanced technology vehicle fleets. This technology maintenance readiness level (TMRL) guide is intended to help fleet operators (such as transit agencies) assess their readiness level with regard to maintaining new advanced technology buses. This guide mirrors a TRL guide but it focuses on the ability of the fleet operator to maintain and repair the advanced vehicle technology rather than defining the commercial readiness of the technology itself. The guide outlines the stages through which a fleet operator progresses to become fully prepared to maintain the selected advanced technology. This includes maintenance staff training, facility upgrades specific to the selected technology (such as adding hydrogen fueling stations or equipment to allow work on high voltage systems), development of maintenance manuals, acquisition of diagnostic and repair tools, and identifying what parts need to be in on-site inventory. By TMRL 9, the fleet operator is fully capable of diagnosing and repairing any issues with the advanced technology, just as they would with conventional vehicle technologies.

Bus purchase costs - The capital cost for FCEBs in 2010 was around $\$ 2.5$ million. More recent orders for FCEBs have had an average cost of $\$ 1.8$ million per bus, which is a $28 \%$ decrease. 
The capital cost should continue to decrease with larger orders of buses. The industry projects an order for 40 buses could result in costs closer to $\$ 1$ million each.

NREL plans to continue monitoring and evaluating the demonstrations at AC Transit, SunLine, and UCI. In the next year, several more FCEBs and operating sites are expected to begin demonstration; these will be included in next year's status report. 


\section{Table of Contents}

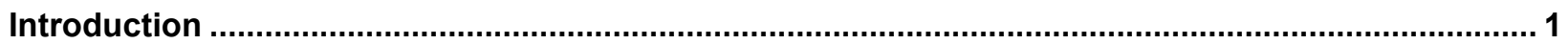

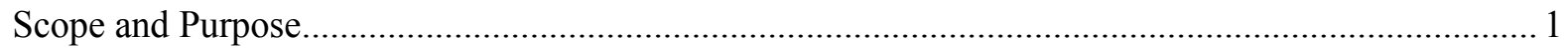

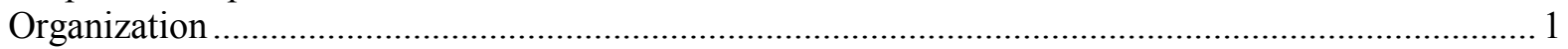

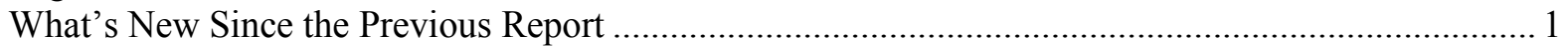

Fuel Cell Electric Buses in Operation in the United States ........................................................ 3

New Fuel Cell Buses Under Development..................................................................................... 3

FCEB Development Process_Technology Readiness Levels ........................................................ 6

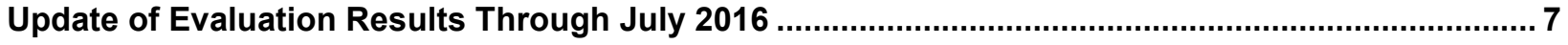

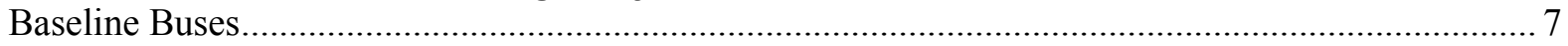

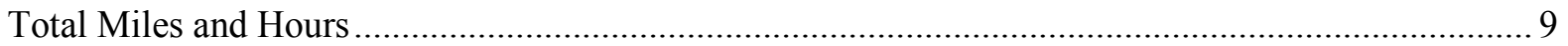

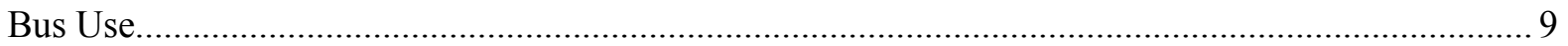

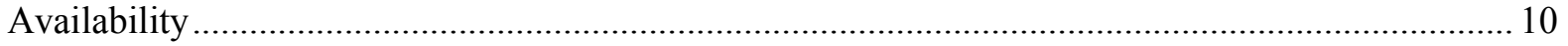

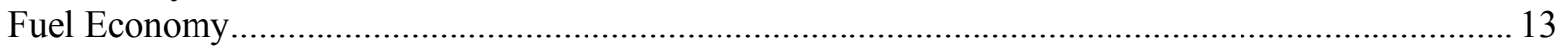

Reliability_Miles Between Roadcalls ........................................................................... 15

Current Status of FCEB Introductions: Summary of Achievements and Challenges ...................... 17

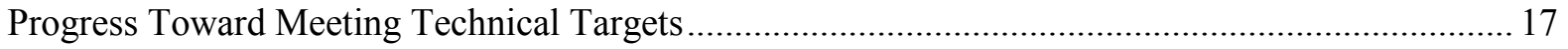

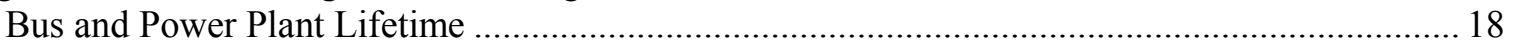

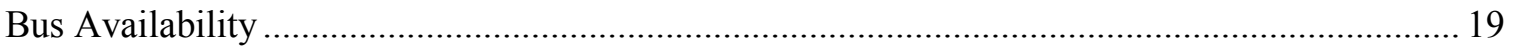

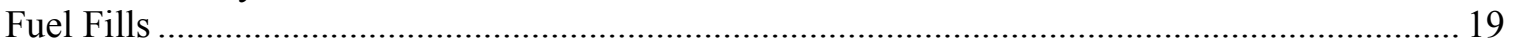

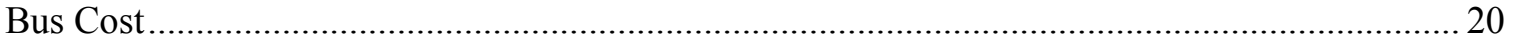

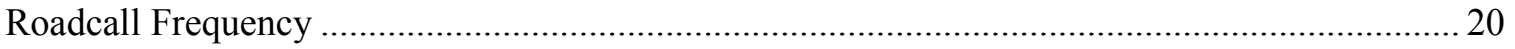

Operation Time

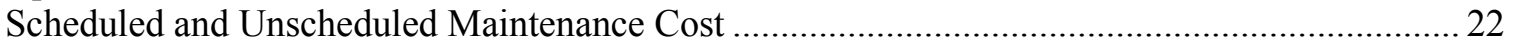

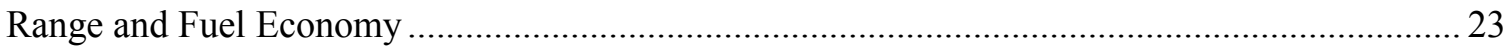

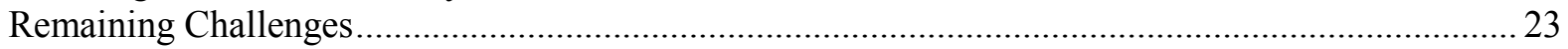

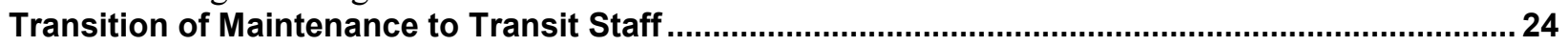

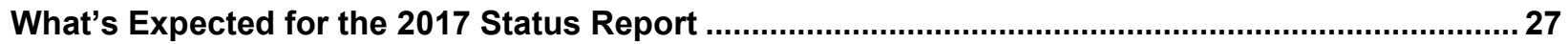

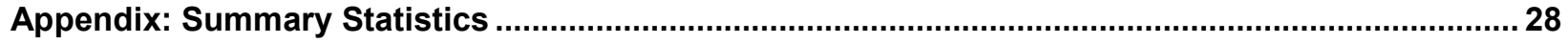

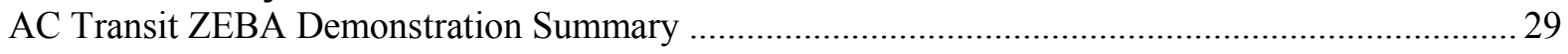

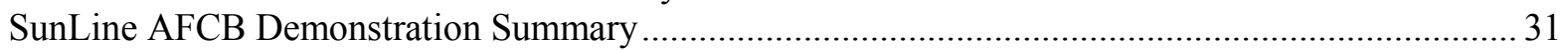

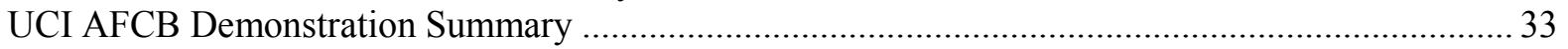




\section{Introduction}

This report is the ninth in a series of annual status reports from the U.S. Department of Energy's (DOE's) National Renewable Energy Laboratory (NREL). It summarizes status and progress from demonstrations of fuel cell transit buses in the United States. Since 2000, NREL has evaluated fuel cell electric bus (FCEB) demonstrations at transit agencies, looking at the buses, infrastructure, and each transit agency's implementation experience. These evaluations have been funded by DOE, the U.S. Department of Transportation's Federal Transit Administration (FTA), and the California Air Resources Board.

\section{Scope and Purpose}

This annual status report discusses the achievements and challenges of fuel cell propulsion for transit and summarizes the introduction of fuel cell transit buses in the United States. It provides an analysis of the combined results from fuel cell transit bus demonstrations evaluated by NREL with a focus on the most recent data (through July 2016). NREL also evaluates the operating experience and costs of these demonstrations individually and posts reports on the NREL website. $^{2}$

The report's intent is to inform FTA and DOE decision makers who direct research and funding; state and local government agencies that fund new propulsion technology transit buses; and interested transit agencies and industry manufacturers.

\section{Organization}

This report is organized into six sections, beginning with this "Introduction." The section "Fuel Cell Electric Buses in Operation in North America" summarizes existing and upcoming demonstrations in the United States and includes an overview of FTA's National Fuel Cell Bus Program (NFCBP) and other programs that promote cleaner options for transit buses. The section "FCEB Development Process - Technology Readiness Levels" outlines the steps for developing and commercializing FCEBs and indicates where each of the current designs falls in the process. The section "Update of Evaluation Results Through July 2016" presents the results of the most recent NREL evaluations of fuel cell transit bus demonstrations with comparisons for availability, fuel economy, and roadcalls. The section "Current Status of Fuel Cell Bus Introductions: Summary of Achievements and Challenges" discusses the status and challenges of fuel cell propulsion for transit. The final section, "What's Expected for the 2017 Report," looks ahead to the results to be presented in next year's assessment report.

Additionally, the "Appendix" provides summary fuel cell bus data from each of the transit agencies.

\section{What's New Since the Previous Report}

Table 1 outlines which FCEB designs were included in the 2015 and 2016 (current) status reports. The 2015 report presented the results from two FCEB demonstration projects featuring fuel-cell-dominant designs. NREL began collecting data on three more projects since the last

\footnotetext{
${ }^{2}$ Website: http://www.nrel.gov/hydrogen/proj_fc bus_eval.html.
} 
report. All three projects involve operating an American Fuel Cell Bus (AFCB) ${ }^{3}$ in service; one at the University of California at Irvine (UCI), one at the Massachusetts Bay Transportation Authority (MBTA) in Boston, and another at Orange County Transportation Authority (OCTA) in Orange County, California. NREL has 7 months of data on the UCI bus, therefore the early analysis is included in this report. The remaining new evaluations will be included in the next status report.

The Proterra FCEB completed operation at Capital Metro in Austin, Texas, and was moved to Flint MTA in Michigan. The EVAmerica FCEB project at Birmingham-Jefferson County Transit Authority (BJCTA) in Birmingham, Alabama, has completed its planned demonstration and has been retired.

Table 1. Technologies Included in the 2015 or 2016 Status Reports

\begin{tabular}{|l|c|c|c|}
\hline \multicolumn{1}{|c|}{ FCEB Demonstration } & $\begin{array}{c}\text { Included in } \\
\text { 2015 Report }\end{array}$ & $\begin{array}{c}\text { Included in } \\
\text { Current Report }\end{array}$ & $\begin{array}{c}\text { Status } \\
\text { (as of 7/31/16) }\end{array}$ \\
\hline $\begin{array}{l}\text { AC Transit Zero Emission Bay } \\
\text { Area (ZEBA) }\end{array}$ & & & Active \\
\hline SunLine AFCB & & & Active \\
\hline UCl AFCB & & & $\begin{array}{c}\text { Active } \\
\text { another location }\end{array}$ \\
\hline Proterra, Austin, TX & & $\begin{array}{c}\text { Demonstration } \\
\text { ended }\end{array}$ \\
\hline BJCTA, Birmingham, AL & & & \\
\hline
\end{tabular}

NREL has developed a technology maintenance readiness level (TMRL) guide for advanced technology vehicle fleets. This guide will help fleet operators (such as transit bus agencies) assess their readiness level with regard to maintaining new zero emission buses.

This guide mirrors a technology readiness level (TRL) guide, but it focuses on the ability of the fleet operator to maintain and repair the advanced vehicle technology rather than defining the commercial readiness of the technology itself. The guide is presented in the Transition of Maintenance to Transit Staff section.

\footnotetext{
${ }^{3}$ The AFCB design was developed through collaboration between BAE Systems, ElDorado National Corporation (ENC), and Ballard Power Systems.
} 


\section{Fuel Cell Electric Buses in Operation in the United States}

Table 2 lists current FCEB demonstrations in the United States. These demonstrations continue to focus on identifying improvements to optimize reliability and durability, but begin to introduce larger fleets of buses. As of August 2016, 21 FCEBs were in active service in demonstrations at several locations throughout the country.

Table 2. Fuel Cell Transit Buses in Active Service the United States

\begin{tabular}{|c|c|c|c|c|}
\hline & Bus Operator & Location & $\begin{array}{l}\text { Active } \\
\text { Buses }^{\text {b }}\end{array}$ & Technology Description \\
\hline 1 & AC Transit, ZEBA ${ }^{a}$ & $\begin{array}{l}\text { San Francisco } \\
\text { Bay Area, CA }\end{array}$ & 13 & $\begin{array}{l}\text { Van Hool bus and hybrid system } \\
\text { integration, US Hybrid support for fuel cell }\end{array}$ \\
\hline 2 & $\begin{array}{l}\text { SunLine Transit } \\
\text { Agency }^{\mathrm{a}} \\
\text { (AFCB prototype) }\end{array}$ & $\begin{array}{l}\text { Thousand Palms, } \\
\text { CA }\end{array}$ & 1 & $\begin{array}{l}\text { ENC/BAE Systems/Ballard next-generation } \\
\text { advanced design to meet "Buy America" } \\
\text { requirements }\end{array}$ \\
\hline 3 & SunLine Transit Agency & $\begin{array}{l}\text { Thousand Palms, } \\
\text { CA }\end{array}$ & 3 & $\begin{array}{l}\text { ENC/BAE Systems/Ballard updated AFCB } \\
\text { design (AFCB) }\end{array}$ \\
\hline 4 & $\begin{array}{l}\text { University of California } \\
\text { at Irvine }\end{array}$ & Irvine, CA & 1 & AFCB \\
\hline 5 & $\begin{array}{l}\text { Massachusetts Bay } \\
\text { Transportation Authority } \\
(\text { MBTA)a }\end{array}$ & Boston, MA & 1 & AFCB \\
\hline 6 & $\begin{array}{l}\text { Orange County } \\
\text { Transportation Authority } \\
(\text { OCTA })^{\mathrm{a}}\end{array}$ & Santa Ana, CA & 1 & AFCB \\
\hline \multirow[t]{2}{*}{7} & Flint MTA & Flint, MI & 1 & AFCB \\
\hline & & Total & 21 & \\
\hline
\end{tabular}

${ }^{a}$ Project received funding through the NFCBP

${ }^{\mathrm{b}}$ Total buses in actual service as of August 2016

NREL is working with the first six demonstrations shown in Table 2. During the last year, NREL collected data on the FCEBs demonstrated in projects 1 through 4. The section "Update of Evaluation Results Through July 2016" provides the most recent results for these four demonstration projects.

\section{New Fuel Cell Buses Under Development}

The FTA has funded several programs that developed zero emission buses for demonstrations in transit agencies.

- NFCBP; a \$180 million, multiyear, cost-share research program for developing and demonstrating commercially viable fuel cell technology for transit buses

- Transit Investments for Greenhouse Gas and Energy Reduction (TIGGER); a \$225 million for capital investments that would reduce greenhouse gas emissions and/or lower the energy use of public transportation systems. 
- Low or No Emission Vehicle Deployment Program (Low-No Program); \$112.5 million in funding (FY13-FY16) to transit agencies for capital purchases of zero-emission and low-emission transit buses that have been largely proven in testing and demonstration efforts, but are not yet widely deployed.

The NFCBP is a multiyear, cost-shared research program established by FTA in 2006, with an overall goal of developing and demonstrating commercially viable fuel cell technology for transit buses. Additional funding was added to the program over the following 4 years. Projects were competitively selected and included fuel cell bus demonstrations, component development projects, and outreach projects. Three nonprofit consortia-CALSTART (Pasadena, California), the Center for Transportation and the Environment (Atlanta, Georgia), and the Northeast Advanced Vehicle Consortium (Boston, Massachusetts) — are responsible for managing the projects. NREL was funded as a third-party evaluator to assess the viability of the buses demonstrated under the program.

Beyond the NFCBP, FTA has funded fuel cell bus research at several universities and transit agencies around the country. The TIGGER program funded a number of zero-emission buses at transit agencies in the United States. The majority of those buses are battery-electric buses; however, SunLine and Flint MTA received funding for FCEBs. These TIGGER projects, listed in Table 2, include an upgraded AFCB design based on lessons learned from the first bus demonstrated at SunLine.

FTA's newest program is the Low-No Program. This program provides funding for capital acquisitions or leases of zero-emission and low-emission transit buses, including battery electric buses and FCEBs. The primary purpose is to deploy the cleanest U.S.-made transit buses that have been proven in testing and demonstrations but are not yet widely deployed in transit fleets. Since the inception of the program, 37 projects were awarded nearly $\$ 132$ million in funding to add low- or zero-emission buses to transit fleets across the United States. At least 174 buses will be deployed through the program including FCEBs, battery electric buses, and hybrid electric buses. The FCEB projects include 13 AFCBs for two agencies; five will be deployed at SunLine and eight will be deployed at Stark Area Regional Transit Authority in Canton, Ohio.

The state of California funds technology development and demonstration programs that include FCEB projects. Both the California Energy Commission (CEC) and the California Air Resources Board (CARB) have funded demonstrations of FCEBs. One of the more recent programs is CARB's Zero-Emission Truck and Bus Pilot Commercial Deployment Projects. Two FCEBrelated projects have been approved for funding. Table 3 lists the new demonstration projects from all funding sources that are expected to field as many as 44 more fuel cell buses over the next few years. 
Table 3. New Fuel Cell Transit Buses Planned in the United States

\begin{tabular}{|c|c|c|c|c|c|}
\hline $\begin{array}{l}\text { Bus } \\
\text { Operator }\end{array}$ & Program & Location & $\begin{array}{l}\text { Total } \\
\text { Buses }\end{array}$ & Technology Description & $\begin{array}{l}\text { Actual/Estimated } \\
\text { Service Start }\end{array}$ \\
\hline $\begin{array}{l}\text { AC Transit } \\
\text { (CALSTART) }\end{array}$ & NFCBP & $\begin{array}{l}\text { Oakland, } \\
\text { CA }\end{array}$ & 1 & $\begin{array}{l}\text { New Flyer } 60 \text {-foot (ft) bus } \\
\text { with next-generation } \\
\text { Hydrogenics fuel cell, } \\
\text { Siemens hybrid propulsion } \\
\text { system }\end{array}$ & $\begin{array}{l}\text { After Altoona } \\
\text { testing ends }\end{array}$ \\
\hline Flint MTA & NFCBP & Flint, MI & 1 & $\begin{array}{l}\text { Proterra battery-dominant } \\
\text { FCEB, Hydrogenics fuel cell } \\
\text { (previously operated in } \\
\text { Austin, TX) }\end{array}$ & Oct 2016 \\
\hline $\begin{array}{l}\text { SunLine } \\
\text { (CALSTART) }\end{array}$ & NFCBP & $\begin{array}{l}\text { Thousand } \\
\text { Palms, CA }\end{array}$ & 1 & $\begin{array}{l}\text { ENC bus with a battery- } \\
\text { dominant fuel cell system } \\
\text { from BAE Systems and a US } \\
\text { Hybrid fuel cell }\end{array}$ & 2017 \\
\hline SunLine & $\begin{array}{l}\text { Low-No } \\
(2015)\end{array}$ & $\begin{array}{l}\text { Thousand } \\
\text { Palms, CA }\end{array}$ & 5 & AFCB & 2017 \\
\hline $\begin{array}{l}\text { SARTAa } \\
\text { OSU }^{\mathrm{b}}\end{array}$ & NFCBP & $\begin{array}{l}\text { Canton, } \\
\text { Columbus, } \\
\mathrm{OH}\end{array}$ & 2 & AFCB & $\begin{array}{c}1^{\text {st }} \text { bus Oct } 2016, \\
2^{\text {nd }} \text { bus at Altoona } \\
\text { for testing }\end{array}$ \\
\hline SARTAa & $\begin{array}{c}\text { Low-No } \\
(2015) \\
\end{array}$ & $\begin{array}{l}\text { Canton, } \\
\mathrm{OH}\end{array}$ & 5 & AFCB & 2017 \\
\hline SunLine & CEC & $\begin{array}{l}\text { Thousand } \\
\text { Palms, CA }\end{array}$ & 1 & $\begin{array}{l}\text { New Flyer Xcelsior } 40-\mathrm{ft} \text { bus, } \\
\text { Hydrogenics fuel cell }\end{array}$ & 2017 \\
\hline SARTA $^{a}$ & $\begin{array}{c}\text { Low-No } \\
(2016) \\
\end{array}$ & $\begin{array}{l}\text { Canton, } \\
\mathrm{OH}\end{array}$ & 3 & AFCB & TBD \\
\hline $\begin{array}{l}\text { AC Transit, } \\
\text { OCTA }\end{array}$ & CARB & $\begin{array}{l}\text { Oakland, } \\
\text { Santa Ana, } \\
\text { CA }\end{array}$ & 20 & $\begin{array}{l}\text { New Flyer bus with Ballard } \\
\text { fuel cell, } 10 \text { buses for each } \\
\text { agency }\end{array}$ & 2018 \\
\hline SunLine & CARB & $\begin{array}{l}\text { Thousand } \\
\text { Palms, CA }\end{array}$ & 5 & $\begin{array}{l}\text { New Flyer bus with } \\
\text { Hydrogenics fuel cell }\end{array}$ & Q1 2018 \\
\hline & & Total & 44 & & \\
\hline
\end{tabular}

${ }^{\text {a }}$ Stark Area Regional Transit Authority

${ }^{\mathrm{b}}$ Ohio State University 


\section{FCEB Development Process-Technology Readiness Levels}

In the 2012 status report, NREL introduced a guideline for assessing the TRL for FCEBs. This guideline was developed using a Technology Readiness Assessment Guide 4 published by DOE in September 2011. NREL presented a TRL guide tailored for the commercialization of FCEBs. The guideline considers the FCEB as a whole and does not account for differing TRLs for separate components or subsystems. Some subsystems may include off-the-shelf components that are considered commercial, while other subsystems may feature newly designed components at an earlier TRL. Figure 1 provides a graphic representation of this process. A table outlining the TRLs and definitions is included in the Appendix.

\section{Commercialization Process}

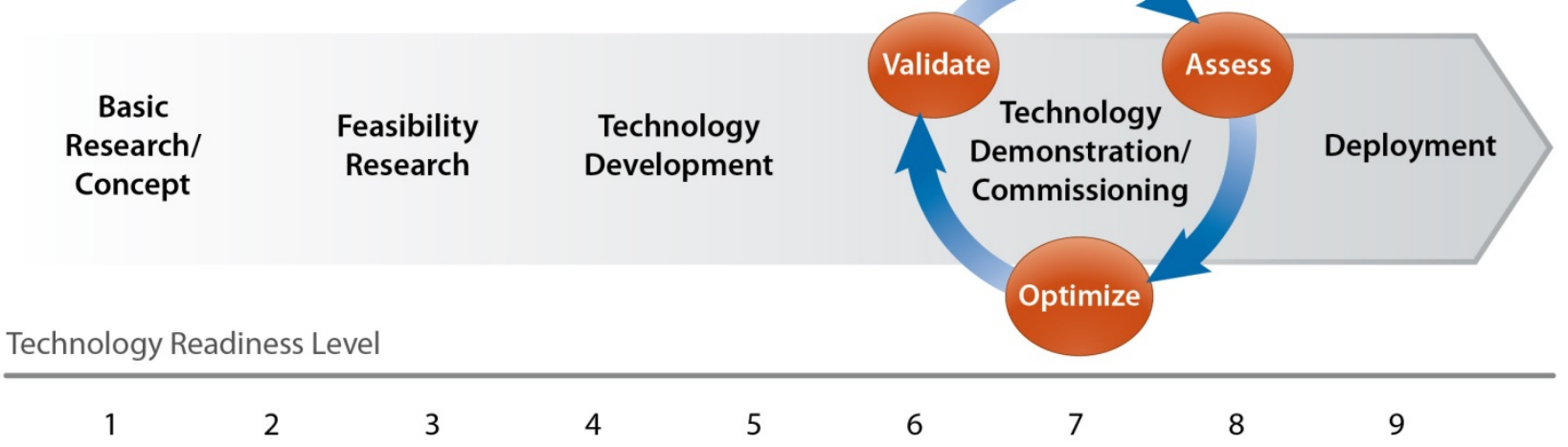

Figure 1. Graphic representation of the commercialization process developed for FCEBs

FCEB development is currently in the technology demonstration/commissioning phase that includes TRLs 6 through 8. This phase begins the process of validating the design, analyzing the results, and reconfiguring or optimizing the design as needed. At this point in development, capital and operating costs for FCEBs are still much higher than those of conventional diesel technology. This is to be expected, considering diesel is a very mature technology (TRL 9) and FCEBs are still in the development stage.

Over the last year, NREL collected data on two different FCEB designs at three demonstration sites. NREL considers both designs to be at TRL7. Both involve manufacturer teams that are experienced with the technology and FCEB fleets of more than 10 buses. These demonstrations represent a full-scale validation in a relevant environment. The ENC buses are built in the United States and meet FTA's "Buy America" requirements. Over the next year, New Flyer will field a new design FCEB based on its current Xcelsior platform. New Flyer's product line for the U.S market meets "Buy America" requirements. The new FCEB design will increase the choices for transit agencies interested in adopting the technology. The larger orders for FCEBs are expected to contribute to further cost reductions.

\footnotetext{
${ }^{4}$ DOE Technology Readiness Assessment Guide, G 143.3-4a, available at http://www2.lbl.gov/DIR/assets/docs/TRL\%20guide.pdf.
} 


\section{Update of Evaluation Results Through July 2016}

The data presented in this section represent the most recent results that have not been presented in a previous annual status report. These data come from three different FCEB demonstrations. To simplify the presentation of the data, each FCEB is assigned an identifier that includes a site abbreviation followed by a manufacturer or project designation. The FCEBs presented in this section have hybrid systems that are fuel cell dominant. Table 4 provides some specifications for each FCEB by the unique identifier. The bus at UCI is the same configuration as the buses at SunLine. The FCEBs are pictured in Figure 2.

Table 4. FCEB Identifiers and Selected Specifications

\begin{tabular}{|l|c|c|c|}
\hline & ACT $^{\text {a ZEBA }}$ & SL AFCB & UCI AFCB \\
\hline Transit agency & AC Transit & SunLine & Anteater Express \\
\hline Number of buses & 13 & 4 & 1 \\
\hline Bus OEMc & Van Hool & ENC & ENC \\
\hline Model/year & A300L/2010 & $\begin{array}{c}\text { Axcess/2011 and } \\
2014\end{array}$ & Axcess/2016 \\
\hline Bus length & $40 \mathrm{ft}$ & $40 \mathrm{ft}$ & $40 \mathrm{ft}$ \\
\hline Gross vehicle weight & $39,350 \mathrm{lb}$ & $43,420 \mathrm{lb}$ & $43,420 \mathrm{lb}$ \\
\hline Fuel cell OEMc & UTC Power & Ballard & Ballard \\
\hline Fuel cell model & Puremotion 120 & FCvelocity HD6 & FCvelocity HD6 \\
\hline Fuel cell power (kW) & 120 & 150 & 150 \\
\hline $\begin{array}{l}\text { Hybrid system } \\
\text { integrator }\end{array}$ & Van Hool & BAE Systems & BAE Systems \\
\hline Design strategy & Fuel cell dominant & Fuel cell dominant & Fuel cell dominant \\
\hline Energy storage OEM & EnerDel & A123 & A123 \\
\hline Energy storage type & Li-ion & Li-ion & Li-ion \\
\hline $\begin{array}{l}\text { Energy storage } \\
\text { capacity }\end{array}$ & $21 \mathrm{kWh}$ & $11 \mathrm{kWh}$ & $11 \mathrm{kWh}$ \\
\hline $\begin{array}{l}\text { Hydrogen storage } \\
\text { pressure (psi) }\end{array}$ & 5,000 & 5,000 & 5,000 \\
\hline Hydrogen cylinders & 8 & 8 & 8 \\
\hline $\begin{array}{l}\text { Hydrogen capacity } \\
\text { (kg })\end{array}$ & 40 & 50 & 50 \\
\hline TRL & 7 & 7 & 7 \\
\hline
\end{tabular}

${ }^{\mathrm{a}}$ AC Transit

${ }^{\mathrm{b}}$ SunLine

${ }^{c}$ original equipment manufacturer

${ }^{\mathrm{d}}$ kilogram

\section{Baseline Buses}

Conventional baseline bus data are provided for comparison with FCEB data when comparable buses are available. Data on baseline buses were included for two of the three sites. For AC Transit, the primary comparison is with Gillig diesel buses. The baseline buses at SunLine are compressed natural gas (CNG) buses because the agency does not operate diesel buses. UCI has a small fleet of diesel buses; however those buses are much older and are not similar in size and weight, so no baseline buses are included in the analysis. The Appendix summarizes the data results by demonstration location and provides additional charts that detail some of the results by agency. 
Data periods included in the report-The report focuses on data from August 2015 through July 2016. The UCI bus was first placed into service in October 2015, but was not operating on a daily basis. Because of that, NREL has set the starting point for the UCI bus to January 2016 once the bus was in regular daily service.

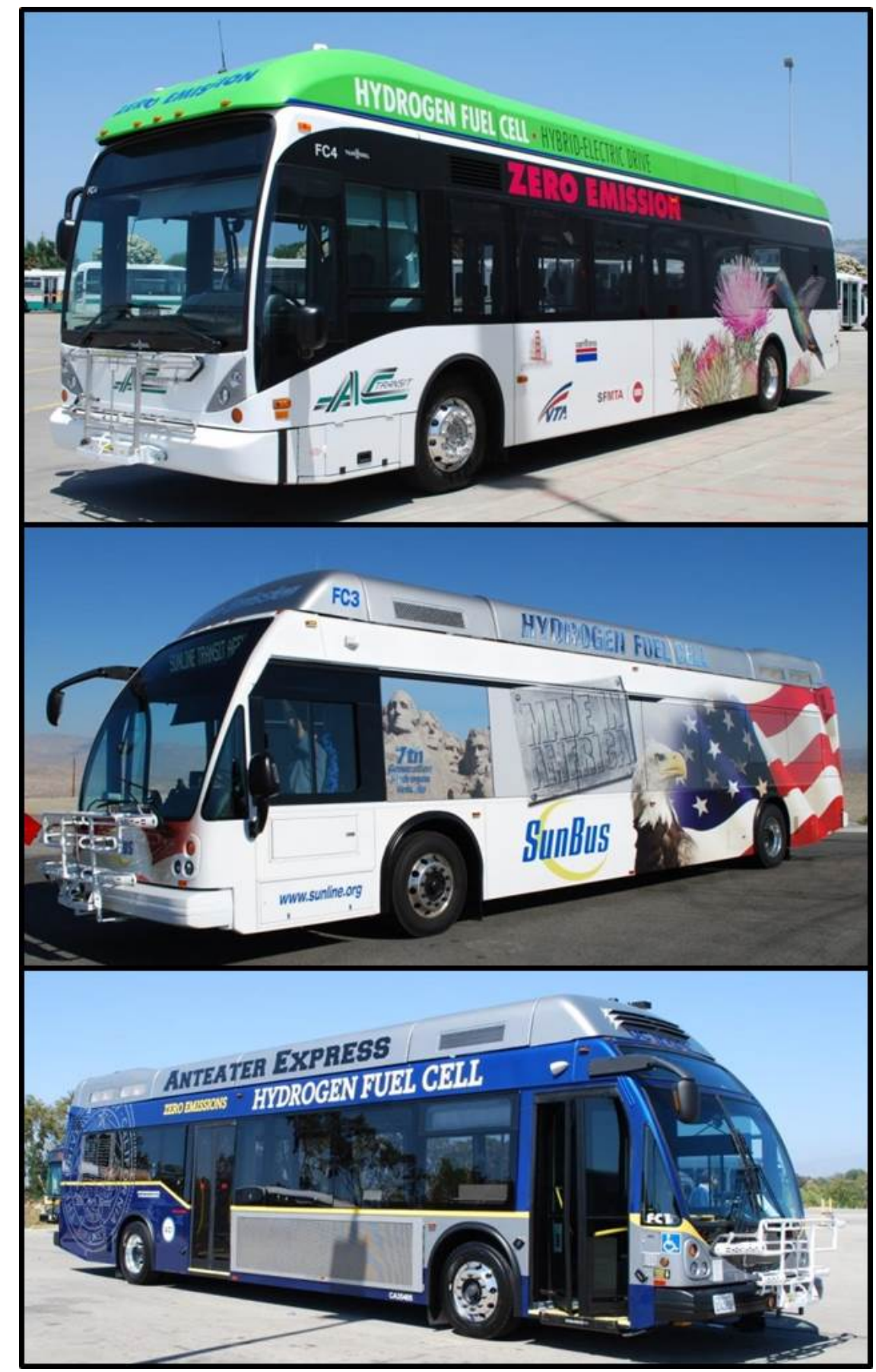

Figure 2. AC Transit ZEBA FCEB (top), SunLine AFCB (middle), and UCI AFCB (bottom) 


\section{Total Miles and Hours}

Table 5 shows miles, hours, average speed, and average monthly miles per bus for the FCEBs. The AFCBs at SunLine have the higher average speed at 13.7 miles per hour (mph). The ZEBA buses in service at $A C$ Transit have a lower average speed of $8.5 \mathrm{mph}$. The average speed of the UCI AFCB has not yet been determined because the hour data on the fuel cell power plant (FCPP) are not complete. The average monthly miles for the group is 2,637 miles per month. This continues the upward trend over time (2,189 miles per month in 2014, 2,464 in 2015). The average monthly miles for the ZEBA buses is $6.5 \%$ higher than last year. The average monthly miles for the SunLine AFCBs increased by $8 \%$ compared with the last reporting period.

Table 5. Miles and Hours for the FCEBs

\begin{tabular}{|l|c|c|c|c|c|c|c|}
\hline \multicolumn{1}{|c|}{ ID } & Period & Months & $\begin{array}{c}\text { No. of } \\
\text { Buses }\end{array}$ & Miles & Hours & $\begin{array}{c}\text { Avg. Speed } \\
(\mathrm{mph})\end{array}$ & $\begin{array}{c}\text { Avg. Monthly } \\
\text { Miles }\end{array}$ \\
\hline ACT ZEBA & $8 / 15-7 / 16$ & 12 & 13 & 412,610 & 48,356 & 8.5 & 2,679 \\
\hline SL AFCB & $8 / 15-7 / 16$ & 12 & 4 & 120,374 & 8,799 & 13.7 & 2,508 \\
\hline UCI AFCB & $1 / 16-7 / 16$ & 7 & 1 & 18,221 & N/A & N/A & 2,603 \\
\hline Overall FCEB & & 29 & 18 & 551,205 & 57,155 & 9.3 & 2,637 \\
\hline
\end{tabular}

\section{Bus Use}

Figure 3 shows the average monthly bus use for the FCEBs and the respective baseline buses. The target of 3,000 miles is included on the chart. All transit agencies have been operating their FCEBs for fewer miles than they operate their baseline buses. Both AC Transit and SunLine have increased service for the buses from what was reported last year. The average monthly miles for the ZEBA buses increased by $7 \%$ and the SunLine monthly miles increased by $9 \%$. SunLine reports that hydrogen station issues late in the data period resulted in limited use of the buses. 


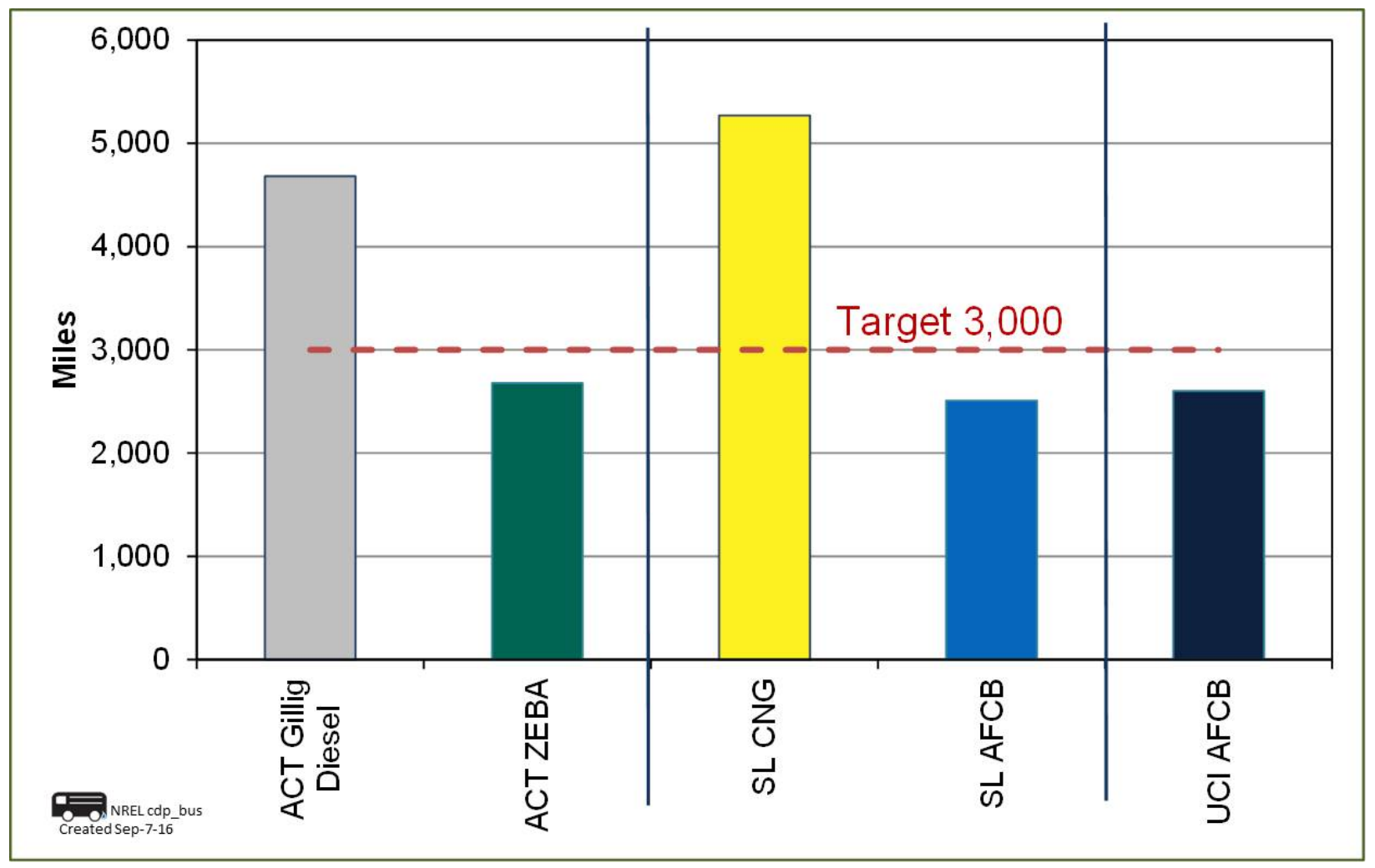

Figure 3. Average monthly mileage for the FCEBs and baseline buses

\section{Availability}

Availability is the percentage of days the buses are actually available out of days that buses are planned for operation. Availability for all of NREL's evaluations is calculated by including the planned service days, which are typically every weekday. Weekends and holidays are included in the calculation only if the bus operated in service on those days. If a bus does not operate on the weekend or on a holiday, it is not counted as unavailable. At AC Transit, the buses are planned to operate every day. At SunLine, the buses are typically planned to operate on weekdays; however, they often operate on weekends as well. The UCI AFCB is operated on campus circulator routes and is planned for weekday service when the university is in session. Table 6 summarizes the availability of the fuel cell buses at each transit agency. Availability for the SunLine and AC Transit fleets was similar, with an average availability of $77 \%$. The UCI AFCB has an average availability of $88 \%$ during the data period. The overall availability for the FCEBs as a group is $77 \% .^{5}$ Figure 4 tracks the monthly availability for the FCEBs by project. The percent availability is shown as a separate colored line for each of the projects with the combined overall average for all of the FCEBs in dashed orange. The availability of the fuel cell system is also included on the chart as a light purple line. During the early part of the data period, the fuel cell system availability was lower than the DOE/FTA target of $90 \%$ due to FCPP issues with several AC Transit buses. As the agency addressed those issues, the fuel cell system availability has increased to around $90 \%$ or better.

\footnotetext{
5 The calculations are based on combining the group of buses as one fleet; therefore the higher availability of the one bus at UCI does not have a significant impact on the overall availability.
} 
Table 6. Availability for the FCEBs

\begin{tabular}{|l|c|c|c|c|c|c|}
\hline \multicolumn{1}{|c|}{ ID } & Period & Months & No. of Buses & Planned Days & Days Avail. & $\%$ Avail. \\
\hline ACT ZEBA & $8 / 15-7 / 16$ & 12 & 13 & 4,697 & 3,635 & $77 \%$ \\
\hline SL AFCB & $8 / 15-7 / 16$ & 12 & 4 & 1,288 & 986 & $77 \%$ \\
\hline UCI AFCB & $1 / 16-7 / 16$ & 7 & 1 & 146 & 129 & $88 \%$ \\
\hline Overall FCEB & & 29 & 18 & 6,131 & 4,750 & $77 \%$ \\
\hline
\end{tabular}

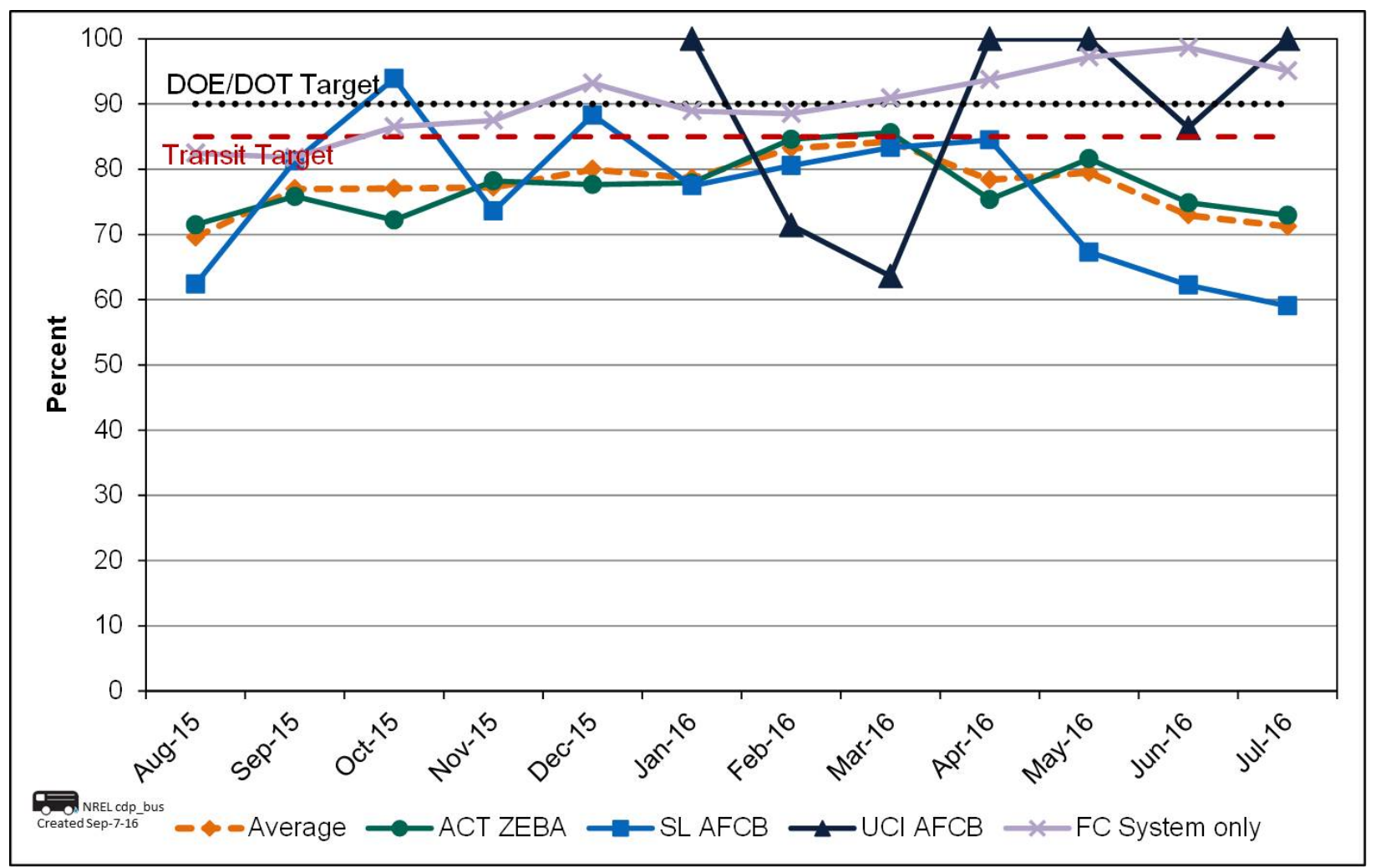

Figure 4. Monthly availability for the FCEBs

Availability for the AC Transit ZEBA FCEBs (dark green line) was more than $70 \%$ for the entire data period. During the last year, individual availability for the 13 buses ranged from a low of $40 \%$ to a high of $92 \%$. Availability was increasing in the early part of the data period as AC Transit diagnosed and repaired issues with the fuel cell systems on two of its buses.

Availability for the SunLine AFCBs (medium blue line) shows some monthly variations over the last year. Individual availability for the four buses ranged between $61 \%$ and $83 \%$ for the data period. Issues with the buses included problems with bus systems such as HVAC and the dashboard. The prototype AFCB was out of service for an extended time from May through June for a system upgrade. During that time, the hybrid system manufacturer completed several upgrades, so the original bus now matches the design of the newer buses.

The UCI AFCB has been in service for less than a year and is achieving an average availability of $88 \%$. During the 7 month data period, the monthly availability of the bus has ranged from just above $60 \%$ to $100 \%$. 
Figure 5 presents individual pie charts that show the overall availability for the data period and separates the reasons for unavailability by category for each of the demonstrations. The data provided for all three demonstrations included the specific reason for each day a bus was not available. This categorization is based on the diagnostic information at that time. Occasionally, an issue proves challenging to troubleshoot and the cause is eventually traced to a system other than that of the original diagnosis. For these cases, NREL changes the unavailability reason retroactively to reflect the updated information. For AC Transit, problems with the fuel cell system were most common, followed by bus-related components. For the SunLine AFCBs, the majority of problems have been for bus-related components, followed by fuel cell system, followed by the hybrid propulsion system components. For the UCI AFCB, there were two primary issues that caused downtime: one with the fuel cell system and one attributed to the hybrid system. 


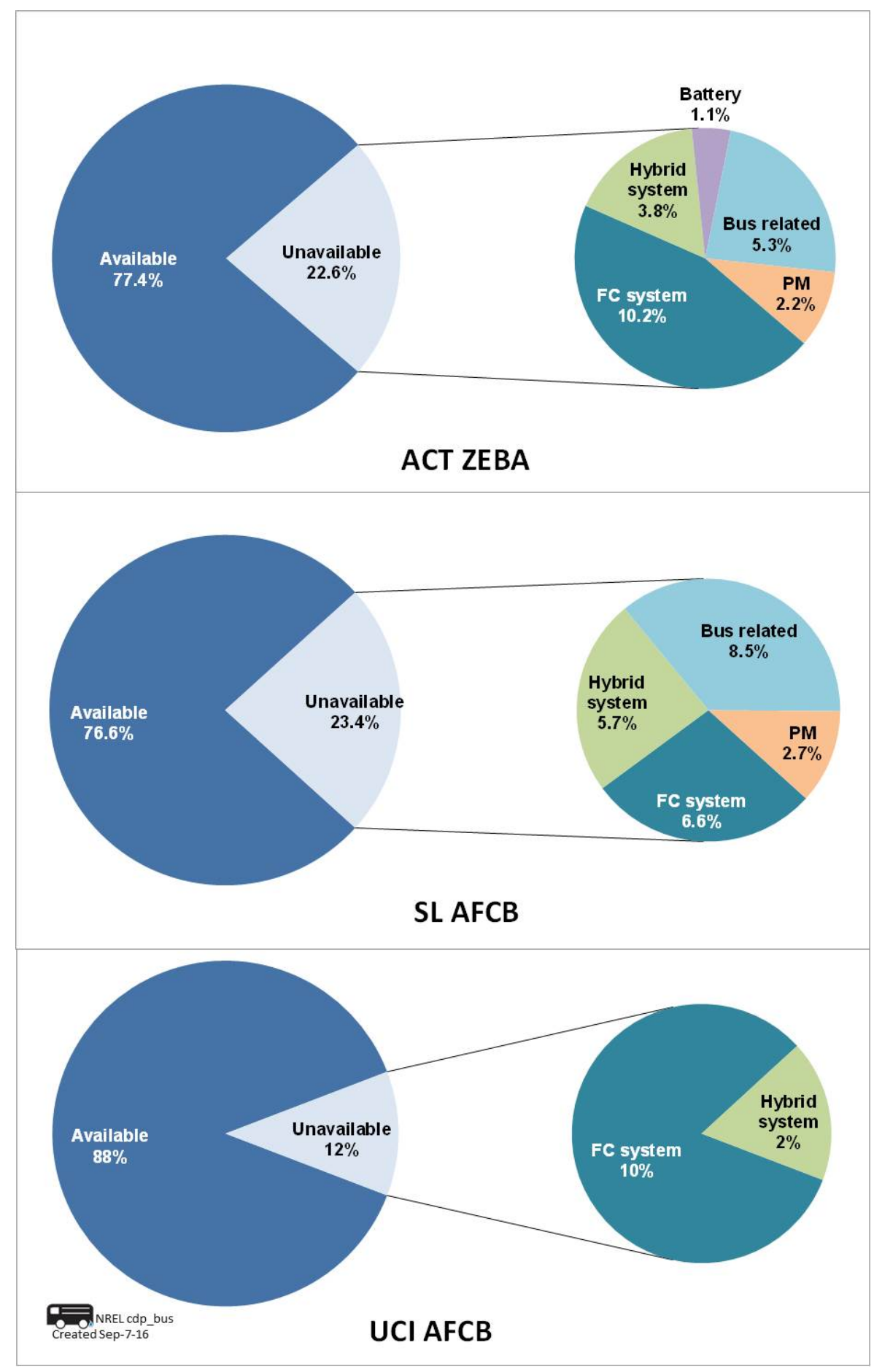

Figure 5. Reasons for unavailability for the FCEBs

\section{Fuel Economy}

Table 7 shows the average fuel economy in miles per diesel gallon equivalent (DGE) for each type of FCEB compared to the conventional baseline bus technology at the same site. The fuel economy for the ZEBA buses is 1.4 times higher than that of the Gillig diesel buses. The AFCBs at SunLine show improved fuel economy that is almost 2 times higher than that of the CNG 
baseline buses. As mentioned previously, the UCI AFCB has no similar baseline buses for comparison.

Table 7. Average Fuel Economy Comparisons Between the FCEBs and Baseline Buses

\begin{tabular}{|l|c|c|c|}
\hline \multicolumn{1}{|c|}{ ID } & $\begin{array}{c}\text { Miles per kg } \\
\text { or GGE }^{\mathrm{a}}\end{array}$ & Miles per DGE & $\begin{array}{c}\text { Difference } \\
\text { from Baseline }\end{array}$ \\
\hline ACT ZEBA & 5.38 & 6.08 & $1.4 \mathrm{x}$ \\
\hline ACT Gillig diesel & - & 4.24 & - \\
\hline SL AFCB & 5.48 & 6.20 & $1.9 \mathrm{x}$ \\
\hline SL CNG & 2.92 & 3.26 & - \\
\hline UCI AFCB & 5.15 & 5.82 & - \\
\hline
\end{tabular}

${ }^{a}$ gasoline gallon equivalent

Figure 6 shows the fuel economy by month over the last year. The FCEBs continue to show improved fuel economy compared to the baseline buses in similar service. The fuel economy for hybrid fuel cell systems tends to vary from site to site depending on the duty cycle.

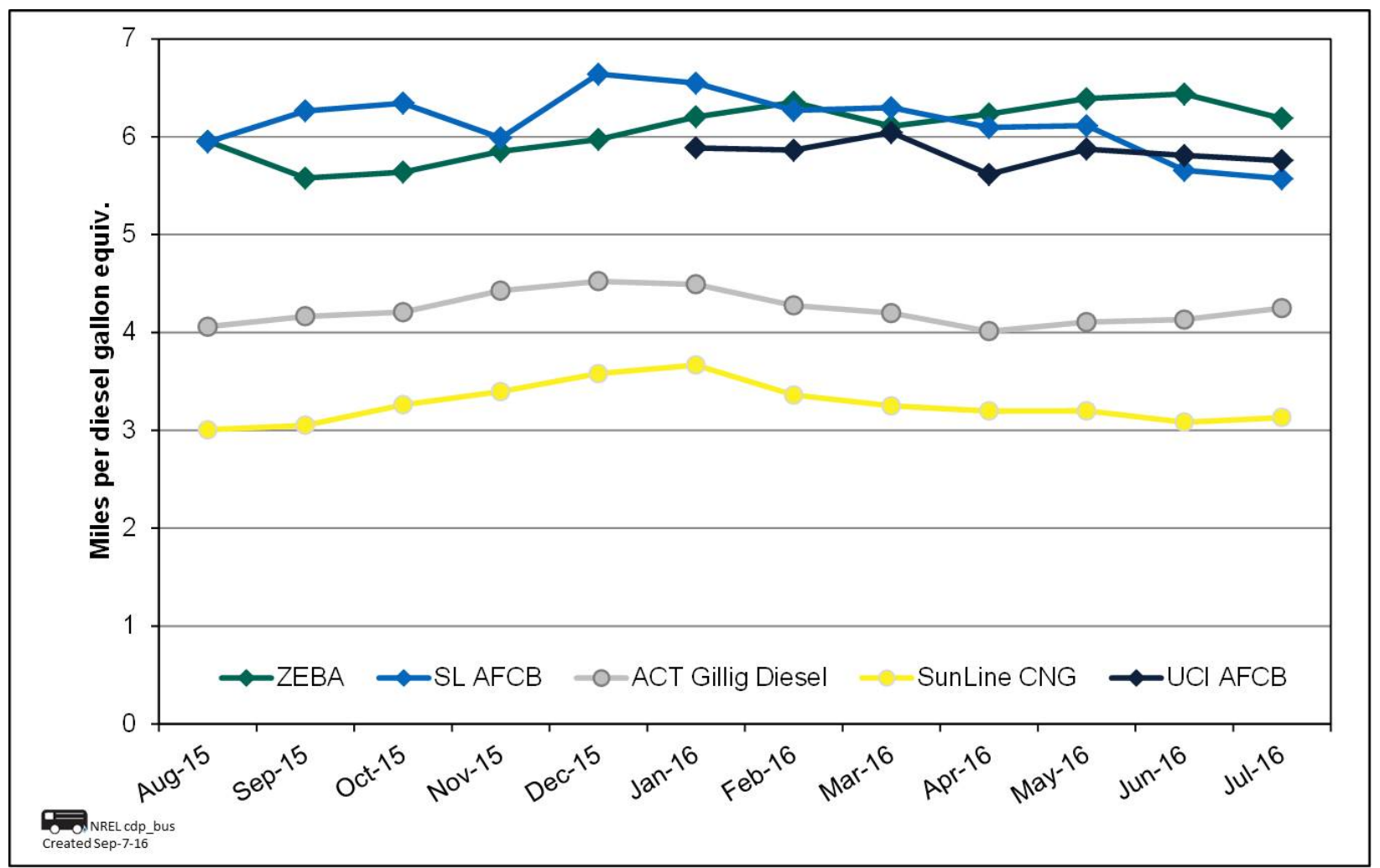

Figure 6. Fuel economy for FCEBs and baseline buses

Over time, the average fuel economy for the fleet has decreased. This decrease could be due to a variety of factors that include:

- Duty cycle-Fuel economy is highly dependent on duty cycle. Characteristics of the routes, such as average speed, terrain, number of stops, and passenger loading, have an effect on efficiency. 
- Operators-Differences in driving styles of the operators could influence efficiency.

- Temperature-Higher ambient temperatures result in increased auxiliary loads for air conditioning.

- FCPP degradation-As fuel cells age, the ability to provide the same power decreases.

- Hydrogen station metering differences between stations-Accurately measuring the amount of hydrogen dispensed has been a challenge for the industry.

\section{Reliability-Miles Between Roadcalls}

A roadcall or revenue vehicle system failure (see the National Transit Database $[N T D]^{6}$ ) is a failure of an in-service bus that causes the bus to be replaced on route or causes a significant delay in schedule. If the bus is repaired during a layover and the schedule is maintained, then no roadcall is recorded. Figure 7 shows miles between roadcalls (MBRC) for bus roadcalls, ${ }^{7}$ propulsion-related roadcalls, ${ }^{8}$ and fuel-cell-system-related roadcalls ${ }^{9}$ for the FCEBs during the data period. The dark blue hashed line marks the DOE/FTA target for bus MBRC $(4,000)$, and the green hashed line is the target for fuel-cell-system-related MBRC $(20,000)$. A secondary target of 10,000 MBRC for propulsion systems is marked with a light blue hashed line. This is not one of the DOE/FTA targets; however, it is a general target for the transit industry. The bus MBRC rates for all three demonstrations are at or above the ultimate target of 4,000. The MBRC for fuel-cell-system-related roadcalls shows that the reasons are not typically due to the fuel cell. The fuel cell system MBRC for the AC Transit ZEBA fleet has surpassed the ultimate target of 20,000 miles.

\footnotetext{
${ }^{6}$ National Transit Database website: www.transit.dot.gov/ntd.

${ }^{7}$ Bus MBRC is all chargeable roadcalls including propulsion-related issues as well as problems with bus-related systems such as brakes, suspension, steering, windows, doors, and tires.

${ }^{8}$ Propulsion-related MBRC includes roadcalls that are attributed to the propulsion system. Propulsion-related roadcalls can be caused by issues with the power system (fuel cell), batteries, and hybrid systems.

${ }^{9}$ Fuel-cell-system-related MBRC includes roadcalls attributed to the fuel cell power plant and balance of plant only.
} 


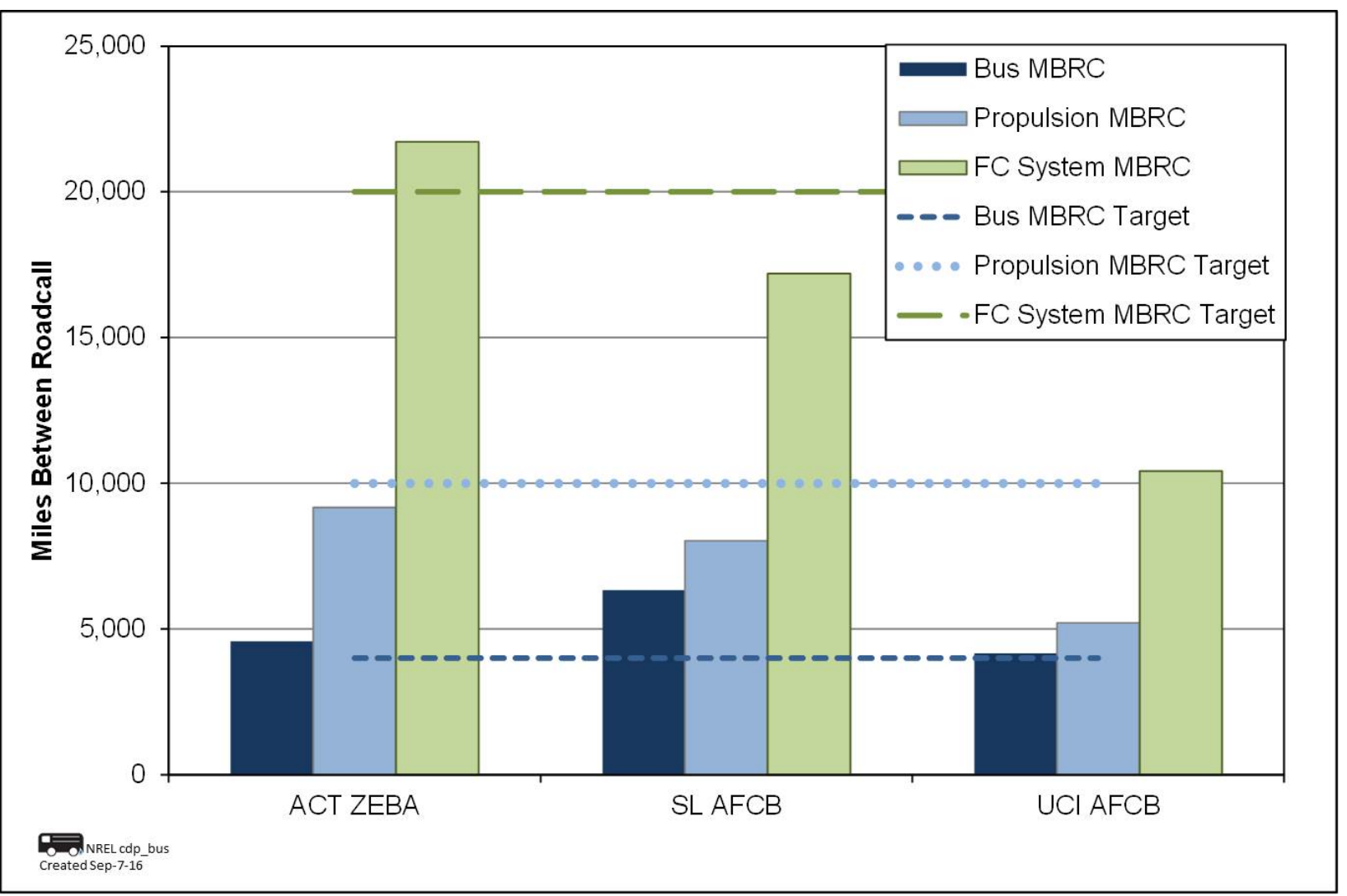

Figure 7. MBRC rates for FCEBs compared to the targets 


\section{Current Status of FCEB Introductions: Summary of Achievements and Challenges}

FCEB technology continues to show progress toward meeting technical targets for increasing reliability and durability while also reducing costs. This section discusses the progress being made and the challenges that remain to bring FCEBs to the market.

\section{Progress Toward Meeting Technical Targets}

DOE and FTA established performance and cost targets for FCEBs. ${ }^{10}$ Interim targets were set for 2016 along with ultimate targets that FCEBs would need to meet to compete with current commercial-technology buses. Table 8 shows a selection of these technical targets for FCEBs.

Table 8. DOE/FTA Performance, Cost, and Durability Targets for FCEBs ${ }^{a}$

\begin{tabular}{|l|c|c|c|}
\hline & Units & 2016 Target & Ultimate Target \\
\hline Bus lifetime & years/miles & $12 / 500,000$ & $12 / 500,000$ \\
\hline Power plant lifetime ${ }^{\mathrm{b}}$ & hours & 18,000 & 25,000 \\
\hline Bus availability & $\%$ & 85 & 90 \\
\hline Fuel fills & per day & $1(<10 \mathrm{~min})$ & $1(<10 \mathrm{~min})$ \\
\hline Bus cost & $\$$ & $1,000,000$ & 600,000 \\
\hline $\begin{array}{l}\text { Roadcall frequency } \\
\text { (bus/fuel cell system) }\end{array}$ & MBRC & $3,500 / 15,000$ & $4,000 / 20,000$ \\
\hline Operation time & hours per day/days & $20 / 7$ & $20 / 7$ \\
\hline $\begin{array}{l}\text { Scheduled and } \\
\text { unscheduled } \\
\text { maintenance cost }{ }^{\mathrm{d}}\end{array}$ & per week & 0.75 & 0.40 \\
\hline Range & Miles & 300 & 300 \\
\hline Fuel economy & miles per DGE & 8 & 8 \\
\hline
\end{tabular}

a The cost targets for subsystems (power plant and hydrogen storage) are not included.

$\mathrm{b}$ The power plant is defined as the fuel cell system and the battery system.

${ }^{c}$ Cost is projected to a production volume of 400 systems per year. This production volume is assumed for analysis purposes only and does not represent an anticipated level of sales.

${ }^{\mathrm{d}}$ Excludes mid-life overhaul of power plant.

Table 9 presents the current status for the FCEBs at TRL 7 toward meeting the DOE/FTA targets. The data are presented for the three fleets (AC Transit, Sunline, and UCI) as a groupthat is, data are combined for all 18 buses. The table includes the fleet minimum and maximum as well as the overall average for the buses as a group. The data for this section include the life and performance beginning at the clean point for each bus.

\footnotetext{
${ }^{10}$ Fuel Cell Technologies Program Record \# 12012, September 12, 2012.
} 
Table 9. Current Status Toward Meeting Performance Targets ${ }^{11}$

\begin{tabular}{|l|c|c|c|}
\hline & $\begin{array}{c}\text { Fleet } \\
\text { Minimum }\end{array}$ & $\begin{array}{c}\text { Fleet } \\
\text { Maximum }\end{array}$ & $\begin{array}{c}\text { Fleet } \\
\text { Average }\end{array}$ \\
\hline Bus lifetime (years) & 0.8 & 6.0 & 4.4 \\
\hline Bus lifetime (miles) & 22,740 & 155,987 & 105,258 \\
\hline Power plant lifetime (hours) & 2,379 & 23,002 & 12,703 \\
\hline Bus availability (\%) & 40 & 92 & 74 \\
\hline Fuel fills (number per day) & 1 & 1 & 1 \\
\hline Bus cost (\$) & $2.1 \mathrm{M}$ & $2.4 \mathrm{M}$ & $2.25 \mathrm{M}$ \\
\hline Roadcall frequency-bus (MBRC) & 2,546 & 7,391 & 4,473 \\
\hline Roadcall frequency-fuel cell system (MBRC) & 7,956 & 143,843 & 20,767 \\
\hline Operation time (average hours per day) & 7.4 & 13.7 & 11.8 \\
\hline $\begin{array}{l}\text { Scheduled and unscheduled maintenance cost } \\
\text { (\$/mile) }\end{array}$ & 0.46 & 2.06 & 1.69 \\
\hline Range (miles) & 214 & 344 & 268 \\
\hline Fuel economy (miles per DGE) & 5.63 & 7.38 & 6.7 \\
\hline
\end{tabular}

\section{Bus and Power Plant Lifetime}

The FTA minimum life cycle requirement for a full-size bus is 12 years or 500,000 miles. ${ }^{12} \mathrm{~A}$ FCPP needs to last about half that time; this compares to a diesel engine that is often rebuilt at about the mid-life of the bus. DOE/FTA set an ultimate performance target of 4 to 6 years (or 25,000 hours) durability for the fuel cell propulsion system, with an interim target of 18,000 hours by 2016. The FCPPs being tracked by NREL continue to accumulate significant numbers of hours. NREL has now collected data on buses for more than half their useful life -6 years. Last year's report documented a single FCPP surpassing 20,000 hours without repair or cell replacement. At the end of the analysis period for this report (July 2016), that FCPP had surpassed 23,000 hours. A second FCPP has now surpassed the 2016 DOE/FTA target of 18,000 hours, having accumulated 18,293 hours. Figure 8 shows the total hours accumulated on the FCPPs for the AC Transit ZEBA fleet (blue bars), the SunLine AFCB fleet (orange bars), and the UCI AFCB (green bar). The DOE/FTA targets for FCPP hours are highlighted in the figure as a green hashed line for the 2016 target and an orange hashed line for the ultimate target; the group average for the 18 FCPPs of 12,302 hours is shown as a red hashed line. Of the 18 total FCPPs included in the graph, 67\% (12) have surpassed 13,000 hours of operation. This shows continued improvement over time toward meeting the 25,000 hour target.

\footnotetext{
${ }^{11}$ Fleet minimum and maximums are for each performance metric and may not necessarily be for the same bus.

${ }^{12}$ FTA Circular 5010.1D: Grant Management Requirements, page IV-17.
} 


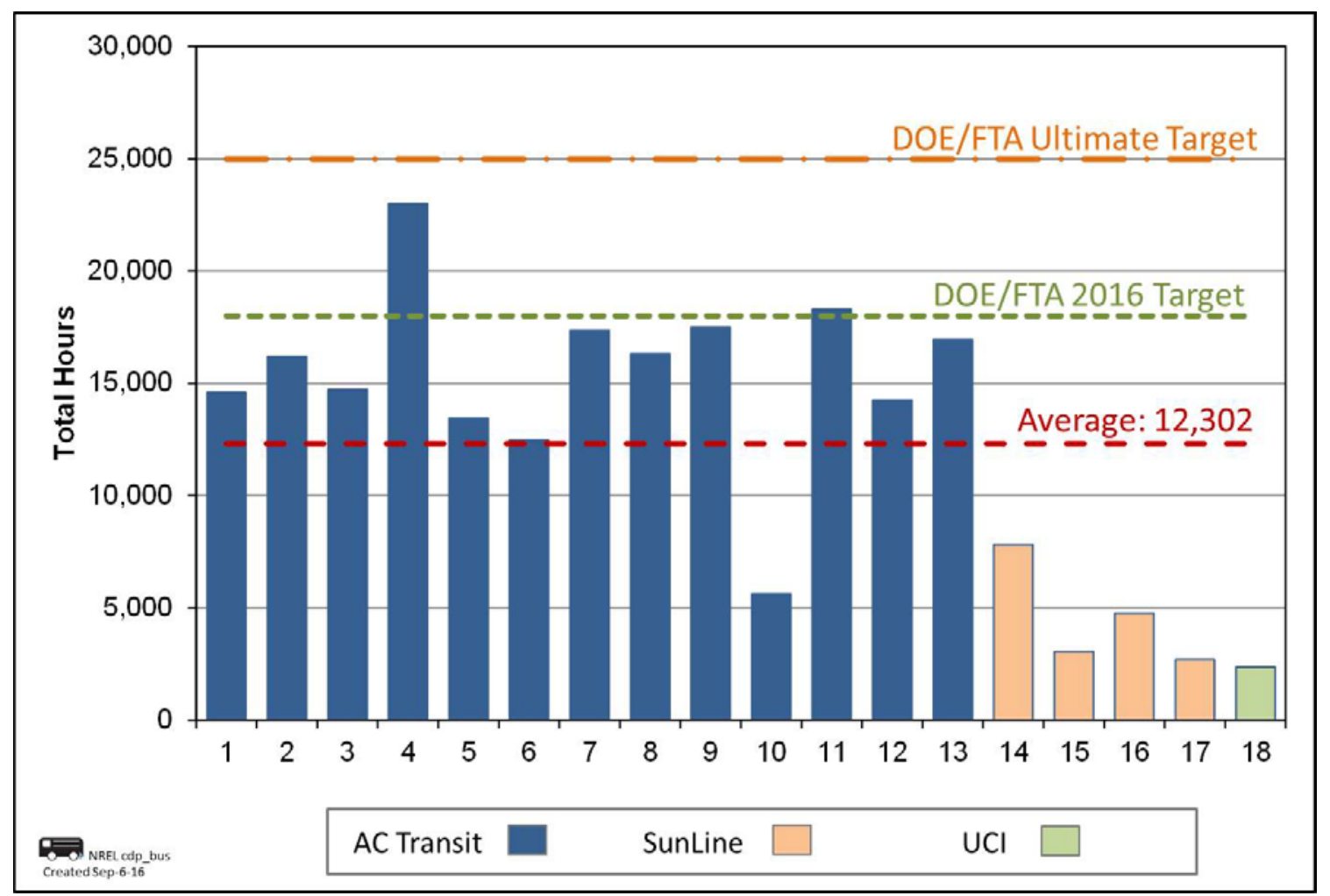

Figure 8. Total hours on the FCEBs through July 2016

\section{Bus Availability}

Availability for the FCEBs ranges from a low of $40 \%$ to a high of $92 \%$ with an overall average of $74 \%$. Many of the issues are attributed to bus-related problems such as brakes, suspension, and air conditioning. Hybrid system problems included issues with components such as traction motor, cooling system, and inverters. Downtime has been extended in some cases because parts have not been readily available. Transit staff continues to learn about the systems and become more proficient in troubleshooting and repairing issues. Downtime is expected to decrease over time.

\section{Fuel Fills}

Transit agencies typically fuel and service buses each evening to prepare them for morning pullout the following day. This results in a 6 to 8 hour window for all of the buses at a specific depot to be prepped. As the buses are being fueled, transit staff is handling other prep work, such as cleaning the interior and emptying the farebox. The time to service each bus is about 10 minutes; therefore the fueling time needs to be 10 minutes or less. Both transit agencies are able to fuel the buses at least once per day. Times for fueling vary between fleets, mainly due to the station designs. SunLine's station typically dispenses hydrogen at about 1 kilogram (kg) per minute, resulting in an average fill time of 22 minutes. AC Transit's stations can fill at rates up to $5 \mathrm{~kg}$ per minute, which results in fill times of less than 10 minutes. The UCI operates a hydrogen station on campus that is primarily for fueling light duty vehicles. The station was upgraded to allow bus fueling; however high station use for cars results in the need for careful management of the bus fueling. The bus uses the same dispenser as the light duty vehicles that fill at 350 bar pressure. The station can fill the bus with up to $32 \mathrm{~kg}$ in a fueling event, which requires a 
recovery period to replenish the hydrogen storage. Because of this, UCI limits bus fueling to a 4hour window during late night hours. The average time to fuel the bus is 24 minutes.

\section{Bus Cost}

Reported costs for FCEBs have not changed since what was reported last year. At this point in the development of FCEB technology, costs are still high. DOE/FTA has set a 2016 target for capital cost of $\$ 1$ million per bus with an ultimate target of $\$ 600,000$ per bus. The AC Transit buses cost \$2.5 million in 2010. More recent orders for FCEBs have had an average cost of \$1.8 million per bus, which is a $28 \%$ decrease. Cost data for planned orders are not yet available. The capital cost should continue to decrease with larger orders of buses. The industry projects an order for 40 buses could result in costs closer to $\$ 1$ million each.

\section{Roadcall Frequency}

The transit industry measures reliability as mean distance between failures, also documented as MBRC. The DOE/FTA targets for roadcall frequency include MBRC for the entire bus and MBRC for the fuel cell system only. Bus MBRC includes all chargeable roadcalls, which means any issue that could physically disable the bus from operating on route. It does not include roadcalls for items such as fareboxes, radios, or destination signs. The fuel cell system MBRC includes any roadcalls due to issues with the fuel cell stack or associated balance of plant.

Each year, NREL presents summary data from the most recent evaluations. As demonstrations end, the data from those evaluations are removed from the combined calculations, while others are added. This makes it challenging to compare the current year's data to previous years because the data set can change significantly. To better illustrate the trend over time for the FCEB designs included in this report, the following MBRC results include reliability data from the current fleets back to the beginning of the evaluation periods. Figure 9 shows the monthly MBRC over time for the bus demonstrations combined. The DOE/FTA 2016 and ultimate targets for bus MBRC and fuel cell system MBRC are included as dashed lines on the chart. Bus MBRC continues to show a gradual upward trend, surpassing the 2016 target and reaching the ultimate target around the end of the previous data period (July 2015). The overall bus MBRC has remained steady over the last year. Fuel cell system MBRC continues to show an upward trend over time, surpassing the ultimate target in early 2015. Over the last year, several fuel-cellrelated roadcalls have caused this number to drop, however it is still over the ultimate target. 


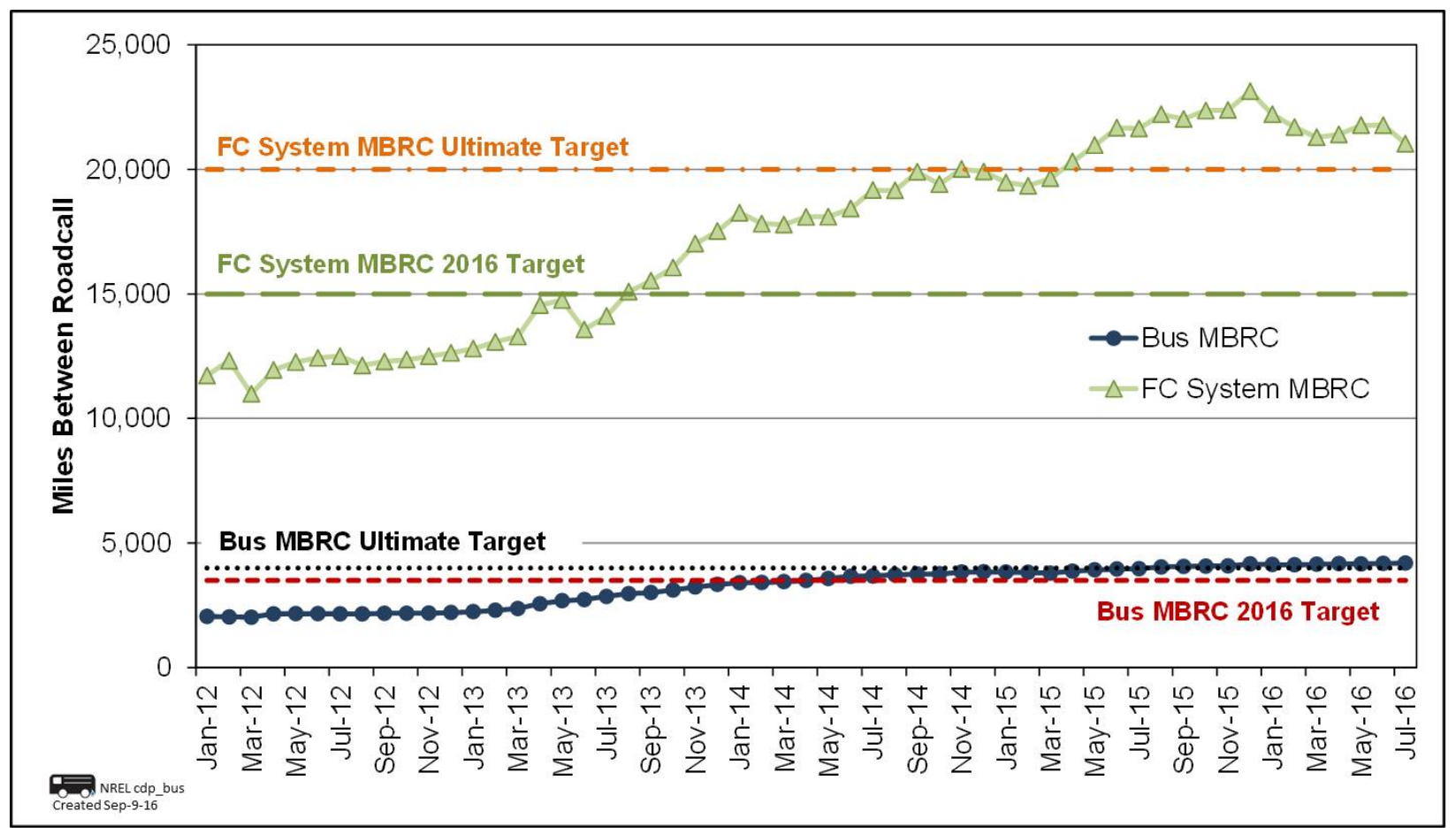

Figure 9. Monthly MBRC for the FCEBs

Table 10 summarizes the MBRC data by year for Figure 9. For each year-long data period (ending in July), the table shows the cumulative bus MBRC, the propulsion system MBRC, and the fuel cell system MBRC. NREL tracks an additional metric of propulsion system MBRC. This category includes all roadcalls due to propulsion-related bus systems. Propulsion-related systems include the fuel cell system (or engine for a conventional bus), electric drive, fuel, exhaust, air intake, cooling, non-lighting electrical, and transmission systems. This metric is important because the primary difference between an advanced technology bus and a conventional bus is the propulsion system. NREL has documented propulsion system MBRC for conventional technologies from 10,000 to more than 20,000 miles.

Table 10. Summary of Cumulative MBRC for the Last 5 Years

\begin{tabular}{|l|c|c|c|c|c|}
\hline & $7 / 2012$ & $7 / 2013$ & $7 / 2014$ & $7 / 2015$ & $7 / 2016$ \\
\hline Bus MBRC & 2,159 & 2,853 & 3,678 & 3,971 & 4,198 \\
\hline Propulsion system MBRC & 3,298 & 4,416 & 6,129 & 6,515 & 7,012 \\
\hline Fuel cell system MBRC & 12,505 & 14,108 & 19,170 & 21,646 & 21,036 \\
\hline
\end{tabular}

Comparison to industry average - Transit agencies are required to report costs and specific performance data to FTA through the NTD. These data are published on the NTD website. ${ }^{13}$ The vehicle maintenance reliability metrics used by the NTD are as follows:

- Major mechanical system failure: A failure of some mechanical element of the revenue vehicle that prevents the vehicle from completing a scheduled revenue trip or from

\footnotetext{
${ }^{13}$ https://www.transit.dot.gov/ntd
} 
starting the next scheduled revenue trip because actual movement is limited or because of safety concerns.

- Other mechanical system failure: A failure of some other mechanical element of the revenue vehicle that, because of local agency policy, prevents the revenue vehicle from completing a scheduled revenue trip or from starting the next scheduled revenue trip even though the vehicle is physically able to continue in revenue service. Examples include a malfunction in the farebox or the air conditioner.

Total revenue system failures would be a sum of the two categories. The NTD categories do not exactly match the definitions used in the standard NREL protocol; however, the data can be used as a general comparison. The primary differences are that the other mechanical system failures category includes failures of items such as fareboxes and headsigns. This results in the NTD total failures being higher than that of the NREL analysis. Removing these failures from the NTD data would result in higher overall industry average MBRC. Also, the NTD major mechanical failure category includes some roadcalls that are not for the propulsion system. The NTD has no category for power plant failures; therefore there is no direct comparison for fuel cell system MBRC.

Using NTD data from 2014, the industry averages are 8,500 MBRC for major mechanical system failure and 4,400 MBRC for total revenue system failure.

\section{Operation Time}

The DOE/FTA target for bus operation is up to 20 hours per day for up to 7 days per week. SunLine and AC Transit report that the buses have operated as many as 21 hours in a single day. AC Transit's buses are scheduled on route blocks that operate from 3 to 21 hours per day. The overall fleet average is just under 12 hours per day. Both agencies report that the buses regularly operate from 5 to 7 days per week. The UCI bus is scheduled to operate on a circulator route that travels from campus to nearby housing. The bus averages approximately 12 hours per day in service.

\section{Scheduled and Unscheduled Maintenance Cost}

The cost data in the table come from the most recent reports published on the projects. For AC Transit, the report published in July $2016^{14}$ covers data through December 2015. For SunLine, the most recent report covers data through June 2016. ${ }^{15}$ The cost data for the UCI bus has not yet been published. As far as operational costs, most FCEB demonstration project buses are still covered under some level of warranty support from the manufacturers. The AFCBs at SunLine are all still under warranty, so nearly all of the maintenance costs are for labor. Maintenance costs for SunLine are currently $\$ 0.46$ per mile. The buses at AC Transit have reached the end of the original warranty period so parts costs have increased. The agency has negotiated extended contracts with the manufacturers, which has added to the overall maintenance costs. AC Transit's maintenance costs are \$2.06 per mile with the extended warranty costs included.

\footnotetext{
${ }^{14}$ Zero Emission Bay Area (ZEBA) Fuel Cell Bus Demonstration: Fifth Report. NREL/TP-5400-66039. Golden, CO: National Renewable Energy Laboratory.

${ }^{15}$ American Fuel Cell Bus Project Evaluation: Third Report. NREL/TP-5400-67209. Golden, CO: National

Renewable Energy Laboratory.
} 


\section{Range and Fuel Economy}

Table 11 lists the fuel economy and hydrogen capacity for the FCEBs in all three demonstrations as well as an overall average for 40-ft buses. Fuel economy for the FCEBs was similar for the three projects, with an average of $5.43 \mathrm{mi} / \mathrm{kg}$. The estimated range is calculated based on the fuel economy numbers and useful fuel amount ( $95 \%$ of the tank's capacity), resulting in an estimated average range for the group of 232 miles.

Table 11. Fuel Economy and Range for the FCEBs

\begin{tabular}{|l|c|c|c|c|}
\hline \multicolumn{1}{|c|}{ ID } & Period & $\begin{array}{c}\text { Fuel Economy } \\
\text { (miles per kg) }\end{array}$ & $\begin{array}{c}\text { Hydrogen Capacity } \\
(\mathrm{kg})\end{array}$ & $\begin{array}{c}\text { Range } \\
\text { (miles) }\end{array}$ \\
\hline ACT ZEBA & $8 / 15-7 / 16$ & 5.38 & 40 & 204 \\
\hline SL AFCB & $8 / 15-7 / 16$ & 5.48 & 50 & 260 \\
\hline UCI AFCB & $1 / 16-7 / 16$ & 5.15 & 50 & 244 \\
\hline Average for 40-ft FCEBs & & $\mathbf{5 . 4 3}$ & & $\mathbf{2 3 2}$ \\
\hline
\end{tabular}

\section{Remaining Challenges}

FCEB performance continues to improve, and new FCEB designs have incorporated the early lessons learned from the first-generation systems. However, there are still challenges to overcome to make the technology commercially viable. This section outlines the ongoing challenges as well as lessons learned from recent issues that occurred over the last year.

Parts supply_-Both AC Transit and SunLine continue to experience some issues with availability of bus components that have a long lead time for delivery. This has improved over time as the project partners have learned what should be kept on hand. In some cases, bus components for the FCEB model are different from that of the diesel model so the bus parts inventory can't be shared. The industry needs to further develop a robust supply chain for these advanced components for FCEBs (as well as other electric drive buses).

Bus range/low fuel-AC Transit has reported that real-world bus range is lower than expected. The agency has reported multiple service calls when the low fuel light comes on while an FCEB is in service. At first, this was attributed to the comfort level of the drivers when the low fuel light comes on. Continued training has helped with this situation and drivers are becoming more familiar with the operational differences over time. The agency has determined that there are other factors that have an effect on the bus range. One factor is training for the staff fueling the buses. Although all staff has been trained on how to fuel the buses, a small group of people handle the majority of fueling duties. That group handles the buses more frequently and has learned how to ensure the buses are getting a full fill. Another factor that affects the ability to fully fuel the bus is the speed of fueling. AC Transit has two hydrogen stations that have different fill rates. A fill at each station might end with the buses' hydrogen tanks being at the same pressure, but the density of the hydrogen in the tank will be lower for the bus fueled at the higher speed because the ending temperature is higher. Once the hydrogen cools, the pressure in the tanks decreases. Also, AC Transit staff frequently transfer between divisions, making it a challenge to transfer knowledge. AC Transit can address the majority of these issues with continued training for its staff. It is difficult to measure real-world range because transit agencies typically fill the buses each day, regardless of the amount of fuel left in the tank. The average fill amount is $22.4 \mathrm{~kg}$ for the three evaluated fleets over the last year. This amount is less than $60 \%$ 
of the tank capacity. The buses are averaging 121 miles per day. This is more a function of how the buses are scheduled as opposed to the actual capability of the bus.

Retention of trained maintenance staff-All transit agencies are experiencing issues with turnover of the most experienced staff through retirements or job changes. Fewer people are entering the field of technical repair, making new candidates scarce. This is particularly challenging for agencies with advanced technology buses, because technical schools are just now beginning to develop courses to handle maintenance and repair of these new technologies. Once these courses are available, there will be a lag time before graduates are ready to enter the market.

Maintenance costs for FCEBs-Maintenance costs for advanced-technology buses typically start low because the buses are under warranty and the manufacturer is covering the cost and taking an active, on-site role in troubleshooting and repair. Costs begin to increase as transit staff takes on more of the maintenance responsibilities and begins the learning curve to understand how to fully maintain the buses. As the staff becomes more proficient, the costs eventually stabilize. NREL does not include warranty costs in its analysis because that initial warranty is covered in the purchase price for the bus. The uncertainty for FCEBs at this point in development is how the parts costs will affect the overall maintenance costs over time once all the buses are out of the initial warranty period. For AC Transit, the buses are out of the original warranty period and parts costs have increased dramatically. The costs for advanced-technology parts are also much higher than those of conventional technology parts. AC Transit has purchased extended support agreements with the manufacturers that also add to the cost and are included in the NREL analysis. Some parts are included in the agreements, but not all are covered. The buses at SunLine and UCI are still under warranty; therefore costs to the agencies are primarily for labor. To help with future planning, transit agencies need to understand future costs as the technology moves into early commercial deployment. Standardization and manufacturing processes could help lower costs for advanced-technology parts and components.

\section{Transition of Maintenance to Transit Staff}

The transition of knowledge from the manufacturers to the transit staff is essential to commercializing the technology. For commercially available bus technologies, the maintenance staff at an agency handles all the preventive maintenance activities while the original equipment manufacturer (OEM) provides most unscheduled maintenance under warranty.

NREL has developed a TMRL guide for advanced technology vehicle fleets. This guide is intended to help fleet operators (such as transit agencies) assess their readiness level with regard to maintaining new zero emission buses $\left(\mathrm{ZEBs}^{16}\right)$. This guide mirrors a TRL guide, but it focuses on the ability of the fleet operator to maintain and repair the advanced vehicle technology rather than defining the commercial readiness of the technology itself. The TMRL guide is outlined in Table 12. At TMRL 1, a fleet operator begins planning for purchase and integration of ZEBs and may be operating a ZEB on loan from the OEM, ${ }^{17}$ which performs all maintenance and repairs of the vehicle at that stage. The guide outlines the stages through which a fleet operator progresses

\footnotetext{
${ }^{16}$ Zero emission buses produce no tailpipe emissions (including FCEBs and battery electric buses).

${ }^{17} \mathrm{OEM}$ (original equipment manufacturer) refers to vehicle manufacturers as well as manufacturers of advanced technology systems/subsystems.
} 
to become fully prepared to maintain the selected ZEB technology. This includes maintenance staff training, facility upgrades specific to the selected technology (such as adding hydrogen fueling stations or equipment to allow work on high voltage systems), development of maintenance manuals, acquisition of diagnostic and repair tools, and identifying what parts need to be in on-site inventory. By TMRL 9, the fleet operator is fully capable of diagnosing and repairing any issues with the advanced technology, just as they would with conventional vehicle technologies.

NREL developed the first draft of the TMRL guide based on the experiences collected from various transit agencies demonstrating advanced technology buses. This guide was shared with all of NREL's current demonstration project representatives for comments and feedback. These demonstrations included FCEB and battery electric bus technologies. NREL improved the guide based on the comments and suggestions provided.

SunLine's staff has been handling the majority of maintenance tasks for several years. The agency's past experience with FCEBs facilitated a quicker transition. Based on the descriptions in the guide, SunLine's staff falls within TMRL 8. AC Transit has successfully transitioned the maintenance to on-site staff as well. Over the last few years, the agency has trained more personnel to cover the FCEB fleet. The agency has access to the service and maintenance manual, wireless diagnostic tools, and other resources to help troubleshoot issues and perform the repairs on site. AC Transit's staff is just moving into TMRL 8. Because the UCI project has recently introduced fuel cell technology into its transit fleet, it is at a much earlier stage. NREL considers the UCI staff to be around TMRL 2 moving into TMRL 3. UCI owns the FCEB and is operating it in expanded service, but it is still relying on the OEM for maintenance. 
Table 12. Technology Maintenance Readiness Levels for ZEBs

\begin{tabular}{|c|c|c|}
\hline $\begin{array}{l}\text { Technology } \\
\text { Maintenance } \\
\text { Readiness } \\
\text { Level }\end{array}$ & TMRL Definition & Description \\
\hline TMRL 9 & $\begin{array}{l}\text { Maintenance staff } \\
\text { fully maintaining } \\
\text { ZEBs }\end{array}$ & $\begin{array}{l}\text { All designated maintenance staff are trained on ZEB technology. } \\
\text { Training is incorporated into standard training program. Spare parts } \\
\text { are readily available for all components. OEMs have regional support } \\
\text { centers or third-party repair facilities are available. Maintenance and } \\
\text { repair training is available from external organizations (e.g., tech } \\
\text { schools, community colleges); incoming maintenance staff is fully } \\
\text { trained. }\end{array}$ \\
\hline TMRL 8 & $\begin{array}{l}\text { Transition of } \\
\text { maintenance to staff } \\
\text { finalized }\end{array}$ & $\begin{array}{l}\text { All maintenance is handled by staff. OEM is off site but available on } \\
\text { an as-needed basis (usually remotely). Full manuals are available } \\
\text { and all special tools and equipment needed have been acquired and } \\
\text { incorporated into the facility. A large percentage of designated } \\
\text { maintenance staff is fully trained. Training curriculum is complete. }\end{array}$ \\
\hline TMRL 7 & $\begin{array}{l}\text { Transition of } \\
\text { maintenance to staff } \\
\text { begins }\end{array}$ & $\begin{array}{l}\text { Select maintenance staff is fully trained and takes on training duties. } \\
\text { OEM makes periodic site visits and provides remote assistance. More } \\
\text { than } 50 \% \text { of designated maintenance staff is fully trained. }\end{array}$ \\
\hline TMRL 6 & $\begin{array}{l}\text { Training transitioned } \\
\text { to select maintenance } \\
\text { staff }\end{array}$ & $\begin{array}{l}\text { OEM is on site, but maintenance staff is doing most maintenance with } \\
\text { supervision. Select maintenance staff is beginning to train other staff. } \\
\text { Maintenance manuals and troubleshooting guides are in final stage of } \\
\text { development. Special tools are available and spare parts supplies are } \\
\text { readily available for most components. }\end{array}$ \\
\hline TMRL 5 & $\begin{array}{l}\text { Training of select } \\
\text { maintenance staff } \\
\text { begins }\end{array}$ & $\begin{array}{l}\text { OEM is on site and begins training select group of maintenance staff } \\
\text { on advanced technology components. Maintenance staff is doing all } \\
\text { general preventive maintenance inspections and vehicle maintenance } \\
\text { but begins assisting OEM with other repairs. Maintenance manuals } \\
\text { and troubleshooting guides are in advanced stage of development. } \\
\text { OEM and fleet owner are developing spare parts list for technology } \\
\text { and identifying what parts need to be in on-site inventory. All } \\
\text { maintenance staff has completed familiarization training. }\end{array}$ \\
\hline TMRL 4 & $\begin{array}{l}\text { Initial implementation } \\
\text { of ZEB technology }\end{array}$ & $\begin{array}{l}\text { OEM is on site doing all maintenance work on advanced technology } \\
\text { components; maintenance staff begins doing vehicle-level } \\
\text { maintenance work and preventive maintenance inspections. } \\
\text { Maintenance manuals and troubleshooting guides are in draft form. } \\
\text { OEM is developing special tools needed for advanced technology } \\
\text { components. Facility modifications are complete. }\end{array}$ \\
\hline TMRL 3 & $\begin{array}{l}\text { Draft training plan } \\
\text { developed }\end{array}$ & $\begin{array}{l}\text { Fleet owns/leases ZEBs, which are used in limited or expanded } \\
\text { service. Fleet develops a training plan and begins to implement } \\
\text { familiarization training for maintenance staff. }\end{array}$ \\
\hline TMRL 2 & $\begin{array}{l}\text { Technology selected } \\
\text { and implementation } \\
\text { planned }\end{array}$ & $\begin{array}{l}\text { Fleet takes ownership/lease of commercially available ZEB. ZEB is } \\
\text { operated in limited service and is fully repaired and maintained by } \\
\text { OEM (without significant zero emission component maintenance from } \\
\text { fleet staff, fleet contractor, or third party repair facility). Maintenance } \\
\text { staff begins to plan for training. }\end{array}$ \\
\hline TMRL 1 & $\begin{array}{c}\text { Initial ZEB } \\
\text { demonstration or } \\
\text { development of } \\
\text { technology of interest }\end{array}$ & $\begin{array}{l}\text { Pre-commercial ZEB (owned by OEM) in limited use by fleet with } \\
\text { additional research and development planned by OEM. Fleet initiates } \\
\text { modifications to facilities for specific technology. }\end{array}$ \\
\hline
\end{tabular}




\section{What's Expected for the 2017 Status Report}

This report includes data from two different FCEB bus designs. In the next year, several new demonstrations should begin, and NREL expects to monitor and evaluate those demonstrations with funding from DOE and FTA. The addition of new FCEB designs and demonstration locations is expected to expand this annual assessment report's scope for determining the status of development. NREL plans to produce several new evaluation reports to present data and experiences from each of these sites.

In addition to the current FCEBs, the following demonstrations (with number of buses in parentheses) are expected to be included in next year's assessment report:

- Next-generation AFCB at Massachusetts Bay Transportation Authority in Boston, Massachusetts (1)

- $\quad$ AFCB at Orange County Transit Authority, Santa Ana, California (1).

NREL will include additional projects if sufficient data are available for the next report. 


\section{Appendix: Summary Statistics}

Table A-1. Technology Readiness Levels for FCEB Commercialization

\begin{tabular}{|c|c|c|}
\hline $\begin{array}{l}\text { Technology } \\
\text { Readiness } \\
\text { Level }\end{array}$ & TRL Definition & Description \\
\hline TRL 9 & $\begin{array}{l}\text { Actual system operated } \\
\text { over the full range of } \\
\text { expected conditions }\end{array}$ & $\begin{array}{l}\text { The technology is in its final form. Deployment, marketing, } \\
\text { and support begin for the first fully commercial products. }\end{array}$ \\
\hline TRL 8 & $\begin{array}{l}\text { Actual system completed } \\
\text { and qualified through test } \\
\quad \text { and demonstration }\end{array}$ & $\begin{array}{l}\text { The last step in true system development. Demonstration } \\
\text { of a limited production of } 50 \text { to } 100 \text { buses at a small } \\
\text { number of locations. Beginning the transition of all } \\
\text { maintenance to transit staff. }\end{array}$ \\
\hline TRL 7 & $\begin{array}{l}\text { Full-scale validation in } \\
\text { relevant environment }\end{array}$ & $\begin{array}{l}\text { A major step up from TRL } 6 \text { by adding larger numbers of } \\
\text { buses and increasing the hours of service. Full-scale } \\
\text { demonstration and reliability testing of } 5 \text { to } 10 \text { buses at } \\
\text { several locations. Manufacturers begin to train larger } \\
\text { numbers of transit staff in operation and maintenance. }\end{array}$ \\
\hline TRL 6 & $\begin{array}{l}\text { Engineering/pilot-scale } \\
\text { validation in relevant } \\
\text { environment }\end{array}$ & $\begin{array}{l}\text { First tests of prototype buses in actual transit service. } \\
\text { Field testing and design shakedown of } 1 \text { to } 2 \text { prototypes. } \\
\text { Manufacturers assist in operation and typically handle all } \\
\text { maintenance. Begin to introduce transit staff to } \\
\text { technology. }\end{array}$ \\
\hline TRL 5 & $\begin{array}{l}\text { Laboratory scale, similar } \\
\text { system validation in } \\
\text { relevant environment }\end{array}$ & $\begin{array}{l}\text { Integrated system is tested in a laboratory under } \\
\text { simulated conditions based on early modeling. System is } \\
\text { integrated into an early prototype or mule platform for } \\
\text { some on-road testing. }\end{array}$ \\
\hline TRL 4 & $\begin{array}{c}\text { Component and system } \\
\text { validation in laboratory } \\
\text { environment }\end{array}$ & $\begin{array}{l}\text { Basic technological components are integrated into the } \\
\text { system and begin laboratory testing and modeling of } \\
\text { potential duty cycles. }\end{array}$ \\
\hline TRL 3 & $\begin{array}{c}\text { Analytical and } \\
\text { experimental critical } \\
\text { function and/or proof of } \\
\text { concept }\end{array}$ & $\begin{array}{l}\text { Active research into components and system integration } \\
\text { needs. Investigate what requirements might be met with } \\
\text { existing commercial components. }\end{array}$ \\
\hline TRL 2 & $\begin{array}{l}\text { Technology concept } \\
\text { and/or application } \\
\text { formulated }\end{array}$ & $\begin{array}{l}\text { Research technology needed to meet market } \\
\text { requirements. Define strategy for moving through } \\
\text { development stages. }\end{array}$ \\
\hline TRL 1 & $\begin{array}{l}\text { Basic principles observed } \\
\text { and reported }\end{array}$ & $\begin{array}{l}\text { Scientific research and early development of FCEB } \\
\text { concepts. }\end{array}$ \\
\hline
\end{tabular}




\section{AC Transit ZEBA Demonstration Summary}

Table A-2. AC Transit Data Summary

\begin{tabular}{|l|c|c|c|c|}
\hline & $\begin{array}{c}\text { ACT } \\
\text { ZEBA } \\
\text { All Data }\end{array}$ & $\begin{array}{c}\text { ACT } \\
\text { ZEBA } \\
\text { Past Year }\end{array}$ & $\begin{array}{c}\text { ACT Gillig } \\
\text { Diesel } \\
\text { All Data }\end{array}$ & $\begin{array}{c}\text { ACT Gillig } \\
\text { Diesel } \\
\text { Past Year }\end{array}$ \\
\hline Data period & $9 / 11-7 / 16$ & $8 / 15-7 / 16$ & $7 / 13-7 / 16$ & $8 / 15-7 / 16$ \\
\hline Number of buses & 13 & 13 & 10 & 10 \\
\hline Number of months & 41 & 12 & 37 & 12 \\
\hline Total miles & $1,414,437$ & 412,610 & $1,714,779$ & 561,804 \\
\hline Total fuel cell hours & 165,068 & 48,356 & - & - \\
\hline Average speed (mph) & 8.6 & 8.5 & - & - \\
\hline Average miles per month & 2,368 & 2,679 & 4,635 & 4,682 \\
\hline Number of scheduled days & 17,155 & 4,697 & 11,280 & 3,670 \\
\hline Number of days available & 12,722 & 3,635 & 9,954 & 3,289 \\
\hline Availability & $74 \%$ & $77 \%$ & $88 \%$ & $90 \%$ \\
\hline Fuel economy (miles per kg) & 5.99 & 5.38 & - & - \\
\hline Fuel economy (miles per DGE) & 6.76 & 6.08 & 4.26 & 4.24 \\
\hline Bus MBRC & 4,462 & 4,585 & 6,859 & 6,242 \\
\hline Propulsion-related MBRC & 7,744 & 9,169 & 14,056 & 9,856 \\
\hline Fuel-cell-system-related MBRC & 21,524 & 21,716 & - & - \\
\hline Total hydrogen used (kg) & 217,133 & 70,516 & - & - \\
\hline SI Units & & & & \\
\hline Total kilometers & $2,276,315$ & 664,031 & $2,759,669$ & 904,136 \\
\hline Average speed (kph) & 13.8 & 13.7 & - & - \\
\hline Average km per month & 3,811 & 4,312 & 7,459 & 7,534 \\
\hline Fuel consumption (kg/100 km) & 10.38 & 11.55 & - & - \\
\hline Fuel consumption (L/100 km) & 31.95 & 35.57 & 55.49 & 55.84 \\
\hline $\begin{array}{l}\text { Bus km between roadcalls } \\
\text { (KBRC) }\end{array}$ & 7,181 & 7,378 & 11,039 & 10,046 \\
\hline Propulsion-related KBRC & 12,463 & 14,756 & 22,620 & 15,862 \\
\hline Fuel-cell-system-related KBRC & 34,640 & 34,949 & - & - \\
\hline
\end{tabular}




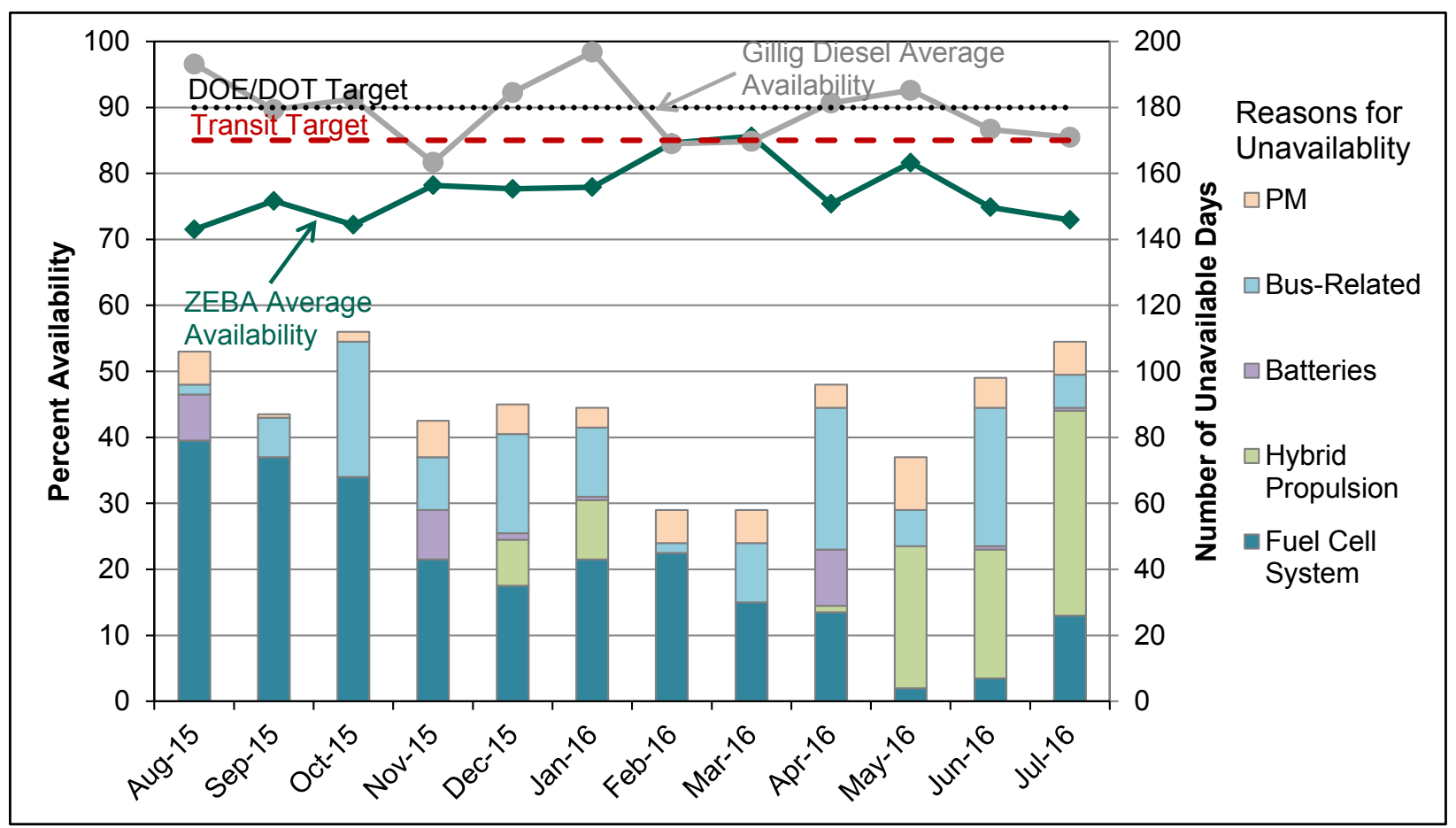

Figure A-1. Monthly availability and number of unavailability days for the AC Transit ZEBA buses

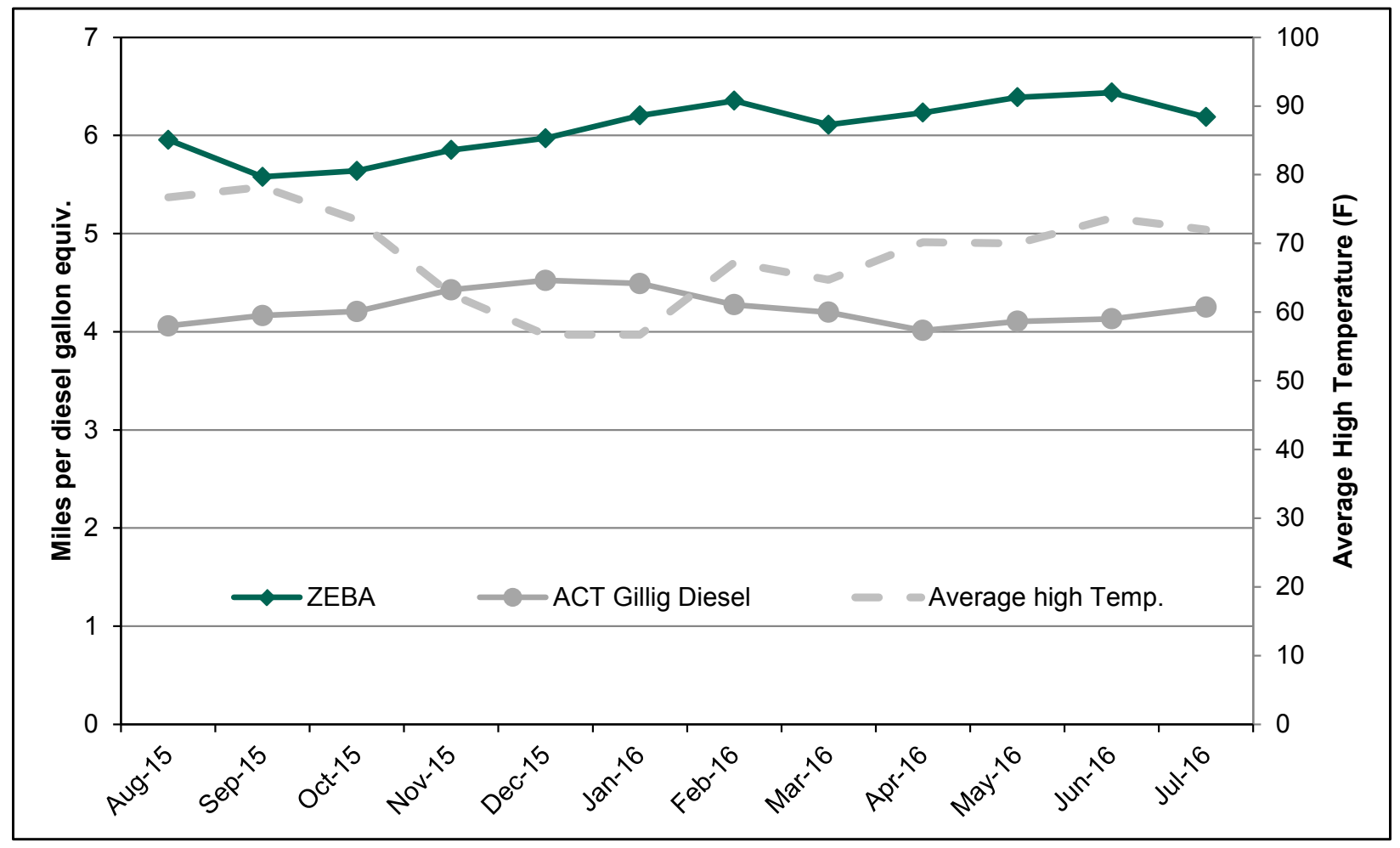

Figure A-2. Monthly fuel economy for the AC Transit ZEBA and diesel buses 


\section{SunLine AFCB Demonstration Summary}

Table A-3. SunLine Data Summary

\begin{tabular}{|l|c|c|c|c|}
\hline & $\begin{array}{c}\text { SL AFCB } \\
\text { All Data }\end{array}$ & $\begin{array}{c}\text { SL AFCB } \\
\text { Past Year }\end{array}$ & $\begin{array}{c}\text { SL CNG } \\
\text { All Data }\end{array}$ & $\begin{array}{c}\text { SL CNG } \\
\text { Past Year }\end{array}$ \\
\hline Data period & $3 / 12-7 / 16$ & $8 / 15-7 / 16$ & $3 / 12-7 / 16$ & $8 / 15-7 / 16$ \\
\hline Number of buses & 4 & 4 & 5 & 5 \\
\hline Number of months & 53 & 12 & 53 & 12 \\
\hline Total miles & 280,761 & 120,374 & $1,242,463$ & 316,102 \\
\hline Total fuel cell hours & 19,833 & 8,799 & - & - \\
\hline Average speed (mph) & 14.2 & 13.7 & - & - \\
\hline Average miles per month & 2,485 & 2,508 & 4,689 & 5,268 \\
\hline Number of scheduled days & 3,002 & 1,288 & 7,212 & 1,666 \\
\hline Number of days available & 2,184 & 986 & 6,254 & 1,546 \\
\hline Availability & $73 \%$ & $77 \%$ & $87 \%$ & $93 \%$ \\
\hline Fuel economy (miles per kg or GGE') & 5.78 & 5.48 & 2.88 & 2.92 \\
\hline Fuel economy (miles per DGE) & 6.53 & 6.20 & 3.21 & 3.26 \\
\hline Bus MBRC & 4,528 & 6,335 & 9,069 & 9,878 \\
\hline Propulsion-related MBRC & 7,019 & 8,025 & 24,362 & 19,756 \\
\hline Fuel-cell-system-related MBRC & 17,548 & 17,196 & - & - \\
\hline Total hydrogen used (kg) & 47,307 & 21,503 & - & - \\
\hline SI Units & & & & \\
\hline Total kilometers & 451,841 & 193,723 & $1,999,550$ & 508,717 \\
\hline Average speed (kph) & 22.8 & 22.0 & - & - \\
\hline Average km per month & 3,999 & 4,036 & 7,545 & 8,479 \\
\hline Fuel consumption (kg/100 km) & 10.75 & 11.33 & - & - \\
\hline Fuel consumption (L/100 km) & 35.07 & 37.18 & 73.62 & 72.61 \\
\hline Bus km between roadcalls (KBRC) & 7,288 & 10,196 & 14,595 & 15,897 \\
\hline Propulsion-related KBRC & 11,296 & 12,915 & 39,207 & 31,795 \\
\hline Fuel-cell-system-related KBRC & 28,240 & 27,675 & - & - \\
\hline
\end{tabular}

${ }^{\mathrm{a}}$ gasoline gallon equivalent 


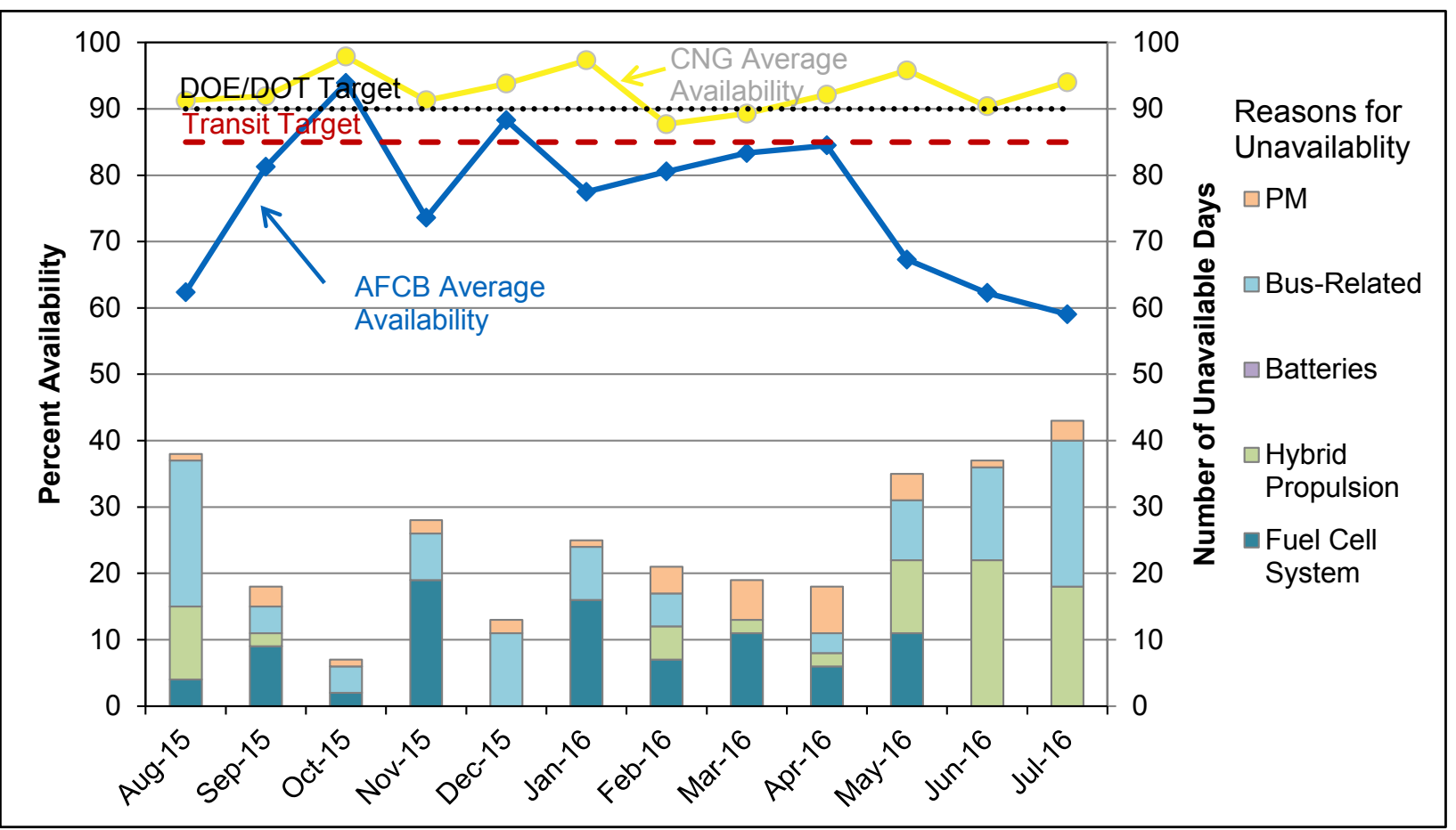

Figure A-3. Monthly availability and number of unavailable days for the SunLine AFCBs

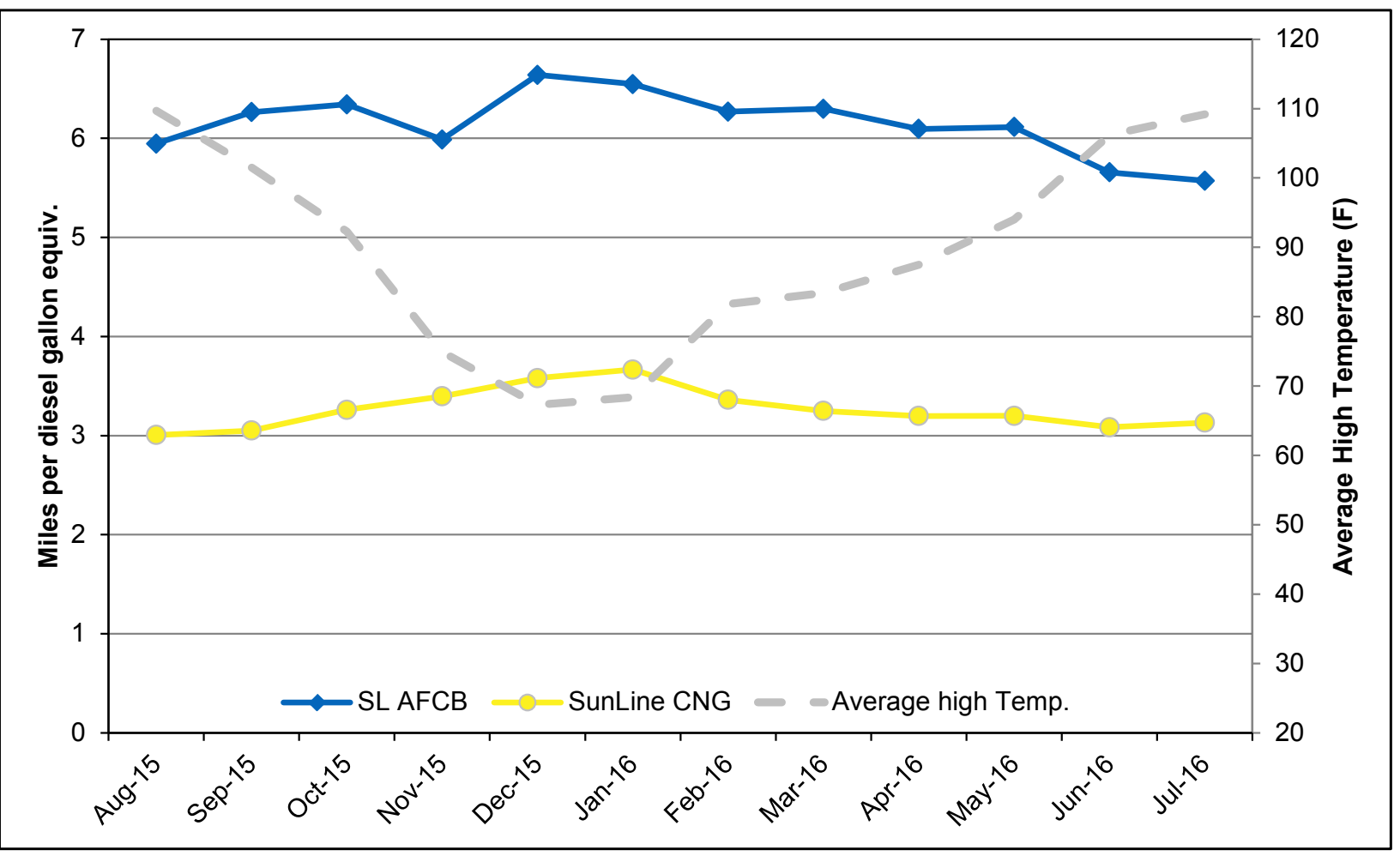

Figure A-4. Monthly fuel economy for the SunLine AFCBs and CNG buses 
UCI AFCB Demonstration Summary

Table A-4. UCI Data Summary

\begin{tabular}{|l|c|}
\hline & $\begin{array}{c}\text { SL AFCB } \\
\text { All Data }\end{array}$ \\
\hline Data period & $1 / 16-7 / 16$ \\
\hline Number of buses & 1 \\
\hline Number of months & 7 \\
\hline Total miles & 18,221 \\
\hline Total fuel cell hours & 2,379 \\
\hline Average speed (mph) & $\mathrm{N} / \mathrm{A}$ \\
\hline Average miles per month & 2,603 \\
\hline Number of scheduled days & 146 \\
\hline Number of days available & 129 \\
\hline Availability & $88 \%$ \\
\hline Fuel economy (miles per kg or GGE) & 5.15 \\
\hline Fuel economy (miles per DGE) & 5.82 \\
\hline Bus MBRC & 4,170 \\
\hline Propulsion-related MBRC & 5,213 \\
\hline Fuel-cell-system-related MBRC & 10,425 \\
\hline Total hydrogen used (kg) & 3401.26 \\
\hline SI Units & \\
\hline Total kilometers & 29,324 \\
\hline Average speed (kph) & $\mathrm{N} / \mathrm{A}$ \\
\hline Average km per month & 4,189 \\
\hline Fuel consumption (kg/100 km) & 12.07 \\
\hline Fuel consumption (L/100 km) & 38.85 \\
\hline Bus km between roadcalls (KBRC) & 6,711 \\
\hline Propulsion-related KBRC & 8,389 \\
\hline Fuel-cell-system-related KBRC & 16,777 \\
\hline
\end{tabular}




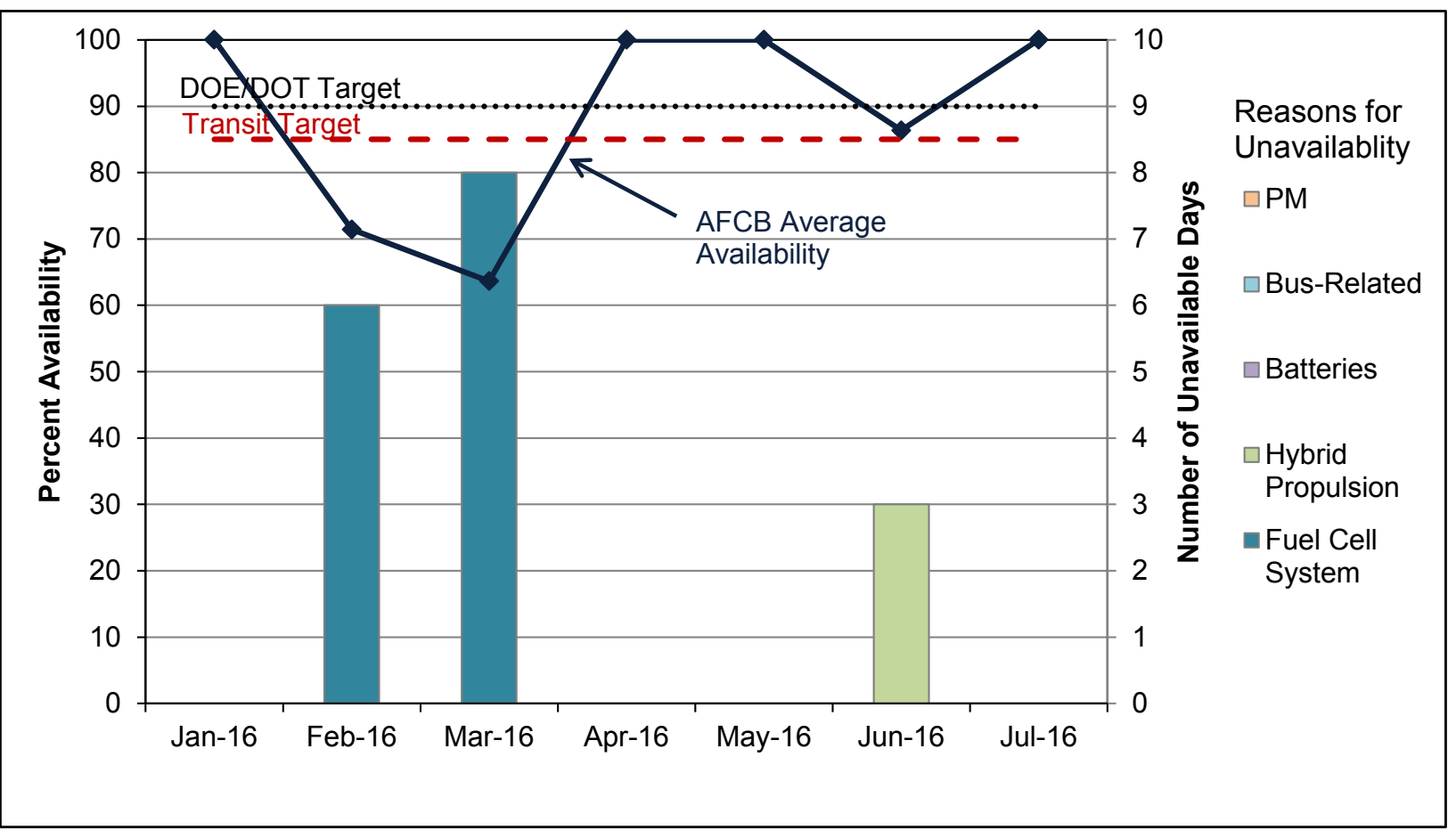

Figure A-5. Monthly availability and number of unavailable days for the UCI AFCB

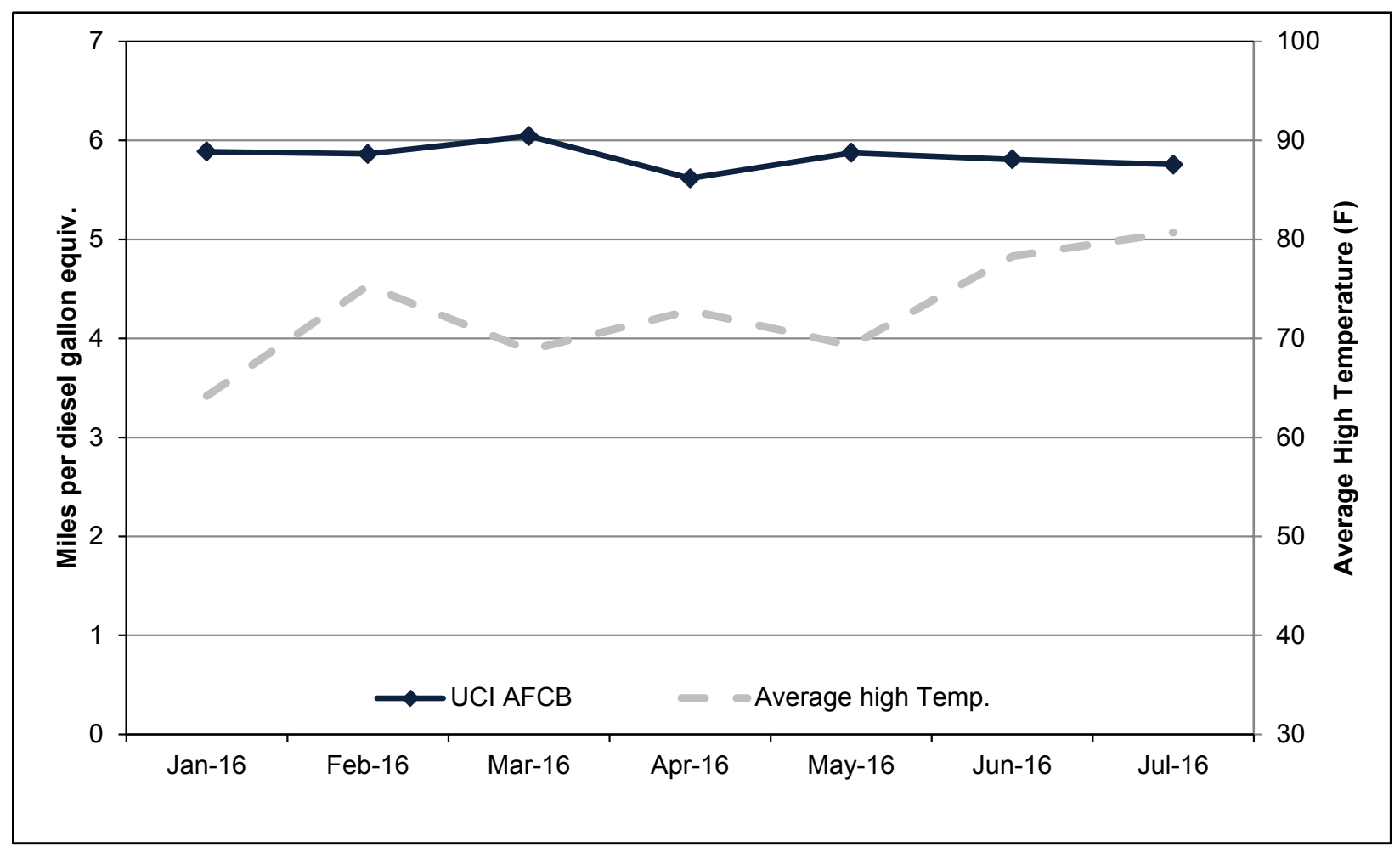

Figure A-6. Monthly fuel economy for the UCI AFCB 